\title{
Making the Case for Megan's Law: A Study in Legislative Rhetoric
}

\author{
DANIEL M. FILLER* \\ INTRODUCTION
}

On July 29, 1994, Jesse Timmendequas raped and murdered his neighbor, sevenyear-old Megan Kanka. ${ }^{1}$ Timmendequas had two prior convictions for sexual offenses against children. ${ }^{2}$ The story of this crime, which occurred in a small central New Jersey community, received national attention. ${ }^{3}$ Within days of Megan's death, Megan's parents, Richard and Maureen Kanka, began a campaign to pressure the New Jersey legislature to adopt a sex-offender community-notification law in her memory. ${ }^{4}$ Their plea was personal and explicitly tied to the death of their daughter. "This was God's

* Assistant Professor of Law, The University of Alabama. A.B., Brown University; J.D., New York University. An earlierversion of this Article was presented at the Southeastern Association of American Law Schools Young Scholars Workshop in 1999. I am deeply appreciative of Wythe Holt and David Hoffman who offered me critical commentary on this work. I also want to thank Amy Adler, Deborah Epstein, Abbe Smith, Norman Stein, and Kent Syverud for their valuable comments and insights. Finally, I want to acknowledge Emily Lassiter's excellent research assistance and the support of Dean Kenneth Randall and the University of Alabama Law School Foundation.

1. John J. Goldman, Sex Offender Guilty of Killing Megan Kanka, L.A. TIMES, May 31, 1997, at A1. The best available proof of Timmendequas's actual guilt is that he was convicted of the crime. The evidence establishing that he committed these crimes was substantial, and it seems exceedingly likely that he is factually guilty. Nonetheless, a criminal conviction is not irrefutable proof of guilt and must be viewed with at least some skepticism. We learn again and again that innocent people are convicted of crimes. See generally JIM DWYER, PETER NEUFELD, \& BARRY SCHECK, ACTUAL INNOCENCE: FIVE DAYS TO EXECUTION AND OTHER DISPATCHES FROM THE W RONGLY CONVICTED (2000).

Indeed, the issue of erroneous conviction surfaced in one of the cases discussed in this Article. Michael Blair was convicted of killing Ashley Estell in Plano, Texas. He was sentenced to death. Recent DNA tests suggest, however, that a hair sample used to tie him to the murder did not come from Blair. Jim Henderson, DNA Tests Raise Questions About Murder Case, Hous. CHRON., July 3, 2000, at 1, LEXIS, News Library, HCHRN File. His attorneys are currently seeking to have his conviction, and death sentence, overturned. Id.

2. Thomas Zambito, New Hearings Will Determine if Wyckoff Rapist Can Be Freed, RECORD (Bergen County, N.J.), Aug. 4, 1994, at A3, LEXIS, News Library, NJREC File.

3. A search of the LEXIS, News Library, ALLNWS File (Megan w/sent Kanka) between August 1, 1994 (the day after Timmendequas's arrest) and August 10, 1994 produced sixty-four hits, reflecting articles in twenty-one different newspapers, representing eighteen cities and one national publication. Given the limited scope of the LEXIS database, as well as both the textual and date limits of the search, this number grossly underestimates the total extent of the incident's coverage.

4. Steven W. Dill, Pink Ribbons Symbolize Drive for Megan's Law, RECORD (Bergen County, N.J.), Aug. 3, 1994, at A3, available at LEXIS, News Library, NJREC File. 
way of using Megan as a tool to make sure this never happens again," Maureen Kanka proclaimed. ${ }^{5}$ The state legislature responded quickly and on October 31, 1994, New Jersey Governor Christine Todd Whitman signed Megan's Law. ${ }^{6}$ The call for new sex-offender registration and community-notification laws spread across the nation, ${ }^{7}$ motivated by the constant recitation of Megan's tragic demise. ${ }^{8}$ Although many states adopted these provisions of their own accord, in 1994 the U.S. Congress passed legislation effectively requiring every state to establish a system for registering certain offenders. ${ }^{9}$ In 1996 Congress raised its demands, requiring every state to provide for community notification as well. ${ }^{10}$ Under pressure from both Congress and public opinion, every state has now adopted some version of Megan's Law. ${ }^{11}$

Support for Megan's Law within both Congress and state legislatures was overwhelming. When community notification came up for discussion in the U.S. House of Representatives, for instance, only one representative voiced opposition. ${ }^{12}$ The provision initially passed the House 415 to 3 , but the three opponents of the

5. $I d$.

6. Joseph F. Sullivan, Whitman Approves Stringent Restrictions on Sex Criminals, N.Y. TIMES, Nov. 1, 1994, at B1.

7. Registration laws require certain convicted offenders to register with state authorities, providing them with a current address. Notification laws allow, or require, dissemination of the registration information to the public at large. In some notification systems, only citizens with an interest in a particular person will be notified; typically, notification is provided within certain geographic areas. In more aggressive jurisdictions, the identity of offenders is widely publicized, frequently via the Internet.

8. The firstsex-offender community-notification law actually predated the Megan Kanka incident. As a result of its own high-profile case of child sexual assault and murder, the state of Washington adopted the Community Protection Act in 1990. W ASH. REV. CODE ANN. $§ ~ 4.24 .550,9$ A.44.130-.140 (West 2000). State adoption of these laws greatly accelerated after Kanka's murder. Alan R. Kabat, Note, Scarlet Letter Sex Offender Databases and Community Notification: Sacrificing Personal Privacy for a Symbol's Sake, 35 A M. CRIM. L. REV. 333, 334-35 (1998).

9. The Jacob Wetterling Crimes Against Children and Sexually Violent Offenders Registration Act, Pub. L. No. 103-322, tit. XVII, § 170101, 108 Stat. 1796, 2038 (1994) (codified as amended at 42 U.S.C. § 14071 (1994 \& Supp. IV 1998)), did not actually require states to adopt registration provisions. States that did not comply with this federal mandate were to lose ten percent of the ir "Byrne Program" criminal justice grants. Id. § 170101(f)(2)(a), 108 Stat. at 2042.

10. See Megan's Law, Pub. L. No. 104-145, 110 Stat. 1345 (1996) (amending 42 U.S.C. $§ 14071(d)(1994)$ ). This provision stated that state law enforcement agencies "shall release relevant information that is necessary to protect the public." Id.

11. Linda Greenhouse, Justices Consider Remedy for Government Grudges, N.Y. TIMES, Jan. 11, 2000, at A16. For a comprehensive list of state registration and notification laws, see Kabat, supra note 8, at 365-70. Several states have adopted their own local "brand name" sex-offender laws. These include Indiana's Zachary's Law, IND. CODE ANN. § 5-2-12-11 (West 2000); North Carolina's Amy Jackson Law, N.C. GEN. STAT. § 14-208.5 (2000); and Texas's Ashley's Law, TEX. CRIM. Proc. CodE AnN. art. 62.01-.12 (Vernon 2001).

12. See infra text accompanying note 177 . 
law-in an apparent search for politicalcover-changed their vote, resulting in a final tally of 418 to $0 .{ }^{13}$ In Florida, legislators did not bother to debate the merits of community notification, adopting the provision unanimously. ${ }^{14}$ Megan's Law passed with similar ease across the country; in Virginia, ${ }^{15}$ Illinois, ${ }^{16}$ and Washington, ${ }^{17}$ for example, it was approved without a single "no" vote.

While Congress and state legislatures were unanimous in their support for sexoffender registration and community-notification laws, others who analyzed the provisions were more critical. Courts struck down portions of these provisions on a variety of grounds. ${ }^{18}$ Commentators in the media expressed serious doubts about the bills. ${ }^{19}$ And, perhaps not surprisingly, legal scholars offered a varied bundle of criticisms of the laws. ${ }^{20}$ Recently, some commentators have suggested that Megan's

13. See 142 CONG. REC. 10,354 (1996).

14. Audio tape: Debate and Vote on H.R. 1665, held by the Florida House of Representatives (April 2,1993) (on file with author); Audio tape: Debate and Vote on S. 56, held by the Florida Senate (May 1, 1995) (on file with author).

15. The General Assembly 1998 Session, VIRGINIAN-PILOT (Norfolk, Va.), Mar. 4, 1998, at B4, LEXIS, News Library, VAPILT File.

16. David Heckelman, House OKs Notice Law Covering Sex Offenders, CHI. DAILY LAW Bull., Nov. 3, 1995, at 1, LEXIS, News Library, CHIDLB File; David Heckelman, Senate OKs Bill Linking Crime Measures, Storage-Tank Repairs, CHI. DAILY LAW BULl., Nov. 16, 1995, at 1, LEXIS, News Library, CHIDLB File.

17. Debera Carlton Harrell, Sex-Offender Notification Guidelines Set; Police Can Defer in Some Cases, Seattle Post-InTElligencer, May 30, 1990, at B1, LEXIS, News Library, SEAPIN File.

18. See, e.g., E.B. v. Verniero, 119 F.3d 1077, 1107-09 (3d Cir. 1997) (striking down provision that placed burden on offender to show he was not sexually violent predator); Roe v. Farwell, 999 F. Supp. 174, 192 (D. Mass. 1998) (striking down notification as violation of double jeopardy and ex post facto clauses); Kansas v. Meyers, 923 P.2d 1024, 1030 (Kan. 1996) (striking down notification as ex post facto law); Louisiana v. Babin, 637 So. 2d 814, 817 (La.Ct. App. 1994) (same); Pennsylvania v. Williams, 733 A.2d 593, 607 (Pa. 1999) (striking down provision that placed burden on offender to show he was not sexually violent predator).

19. See, e.g., Community Quandary, ProvidenCE J.-Bull., Apr. 15, 1996, at 4B, LEXIS, News Library, PRVJNL File (encouraging states to focus on rehabilitation); Suzanne Fields, Worrying About the Monster in Our Midst, DALLAS MORNING NEWS, Mar. 3, 1995, at 25A, LEXIS, News Library, DALNWS File (arguing that only life sentences for sex offenders provide safety); Good Intentions Can Lead to Bad Laws, HARTFORD COURANT, Jan. 20, 1995, at A12, LEXIS, News Library, HTCOUR File (suggesting such laws are unconstitutional); John Q. LaFond, Beware Illusory Remedies, USA TODAY, Aug. 11, 1994, at 12A (arguing laws will not make communities safer); Cathy Young, Look Before Leaping on Megan's Law, DETROIT NEWS, May 21, 1996, at 12, LEXIS, News Library, DTNEWS File (claiming that rehabilitation and appropriately longer sentences are better solutions to sex crimes).

20. See, e.g., Caroline Louise Lewis, The Jacob Wetterling Crimes Against Children and Sexually Violent Offender Registration Act: An Unconstitutional Deprivation of the Right to Privacy and Substantive Due Process, 31 HARV. C.R.-C.L. L. REV. 89 (1996); Toni M. Massaro, Shame, Culture, and American Criminal Law, 89 MiCH. L. REV. 1880 (1991); Symposium, Critical Perspectives on Megan's Law: Protection vs. Privacy, 13 N.Y.L. SCH. J. HUM. RTS. 1 (1996) [hereinafter Symposium] 
Law reflects a recurring type of "moral panic," a widespread, if overblown fear that the nation's children are at extreme risk. ${ }^{21}$

Megan's Law is controversiallegislation because it targets a narrow segment of the criminal-offender population, sex offenders, subjecting them to public shame and, potentially, vigilante violence. Offenders' names and faces are distributed throughout the community. Schools send notices home with the children, ${ }^{22}$ police mail grainy pictures to anxious neighbors, and an entire nation peruses sex offender photos on state-operated Web sites. ${ }^{23}$ Legislators openly acknowledged that the provis ions' benefits came at significant cost to offenders' privacy and security. ${ }^{24}$

This Article does not attempt to judge Megan's Laws on functional, constitutional, or sociological grounds. Others have taken on these tasks. ${ }^{25}$ Moreover, it is unlikely that politicians would revoke these provisions, even in the face of trenchant new critiques. Instead, it explores the role of legislative debate rhetoric in the adoption of these seemingly unstoppable bills.

In recent years, legal scholarship has increasingly focused on the rhetoric of law. ${ }^{26}$

(including critical comments from Hon. John J. Gibbons, Ronald K. Chen, Eric Janus, and others); Abril R. Bedarf, Comment, Examining Sex Offender Community Notification Laws, 83 CAL. L. REV. 885 (1995); Michelle L. Earl-Hubbard, Comment, The Child Sex Offender Registration Laws: The Punishment, Liberty, Deprivation, and Unintended Results Associated with the Scarlet Letter Laws of the 1990's, 90 NW. U. L. REV. 788 (1996); Jenny A. Montana, Note, An Ineffective Weapon in the Fight Against Child Sexual Abuse: New Jersey's Megan's Law, 3 J.L. \& PoL'Y 569 (1995); G. Scott Rafshoon, Comment, Community Notification of Sex Offenders: Issues of Punishment, Privacy, and Due Process, 44 EMORY L.J. 1633 (1995); Jane A. Small, Note, Who Are the People in Your Neighborhood? Due Process, Public Protection, and Sex Offender Notification Laws, 74 N.Y.U. L. REV. 1451 (1999).

21. See, e.g., PhILIP Jenkins, Moral PANIC: Changing CONCEPTS OF THE CHILD MOLESTER IN MODERN A MERICA 6-7, 196-206 (1998). The term was coined by British sociologists during the early 1970s. See, e.g., STANLEY COHEN, FOLK DEVILS AND MORAL PANICS: THE CREATION OF THE MODS AND ROCKERS 191-98 (1972).

22. E.g., Maggie Haberman \& Susan Edelman, Queens Schools to Post Pix of Sex Offenders, N.Y. POST, Nov. 15, 1998, at 6 (stating that one New York City school district would send pictures of local sex offenders home with 36,000 students).

23. One Web site, www.sexoffender.com, provides links to a number of different states' sexual-offenderpostings. At the time of this writing, a visitor to this site could find links to over twenty different state registries. See http://www.sexoffender.com (last visited Oct. 16, 2000).

24. See 142 CONG. REC. 10,313 (1996) (statement of Rep. Cunningham).

25. See, e.g., Kabat, supra note 8; Brian J. Telpner, Note, Constructing Safe Communities: Megan's Laws and the Purposes of Punishment, 85 GEO. L.J. 2039 (1997); Ellen Liberman, Megan 's Law's Unintended Result: Hysteria, PROVIDENCE J.BULL., Oct. 17, 1999, at 1A, LEXIS, News Library, PRVJNL File; see also supra note 20 and accompanying text.

26. The term rhetoric is used here to refer to "the conventions of discourse and argument." Gerald B. Wetlaufer, Rhetoric and Its Denial in Legal Discourse, 76 VA. L. REV. 1545, 1546 (1990). Plato's Gorgias argued that rhetoric included "power to persuade by speech jurymen in the jury-court, council-men in the Council Chamber, assembly-men in the Assembly, and in every other gathering, whatever political gathering there may be." Plato, GORGIAS § 452e, at 19 (Terence Irwin trans., 
The central role of rhetoric in law has always been obvious, of course. ${ }^{27}$ The entire first year of law school, for instance, is dedicated to refining students' skills in reading, understanding, and analyzing judicial opinions. Students spend hours learning how to make, and refute, legal claims based on the slightest linguistic nuances of court decisions. Supreme Court opinions begin to take on almost talmudic importance, as students search within the concurring opinions for a word here, or a phrase there, that offers a hint to the Court's future leanings. These law school exercises are only the beginning. Lawyers and legal scholars build entire careers on the facile use of rhetoric. For years, legal scholarship engaged in rhetorical analysis unselfconsciously, attempting to square legal precedents and parsing the language of judicialopinions. Rarely did they acknowledge the se opinions were not themselves truths but, rather, rhetorical claims. ${ }^{28}$

The tide has turned, however. More and more, commentators explicitly explore the role of rhetoric in constructing law, legal power relationships, and even public perceptions of social crises that lead to new legislation. ${ }^{29}$ Legal scholars study the nature and power of judicialrhetoric. ${ }^{30}$ Some write about the importance of courtroom

Clarendon Press 1979)). For an extensive discussion of the rhetorical tradition, see George A. Kennedy, Classical Rhetoric AND Its Christian and SECUlar TRADITION FROM A NCIENT TO MODERN TIMES (2d ed., rev. \& enl. 1999).

27. As one commentatornoted, "law is the very profession of rhetoric." Wetlaufer, supra note 26, at 1554 .

28. Id. at 1555 ("[I]f law is, at its core, the practice of rhetoric, the particular rhetoric that law embraces is the rhetoric of foundations and logicaldeductions. And that particular rhetoric is one that relies, above all else, upon the denial that it is rhetoric that is being done.") (emphasis in original); James Boyd White, Law As Rhetoric, Rhetoric As Law: The Arts of Cultural and Communal Life, 52 U. CHI. L. REV. 684, 685 (1985) ("[T] he law is at present usually spoken of (by academics at least) as if it were a body of more or less determinate rules, or rules and principles, that are more or less perfectly intelligible to the trained reader.").

This is not to suggest that words are inconsequential. Their interpretation can have dramatic tangible consequences. As Robert Cover explained, "Legalinterpretive acts signal and occasion the imposition of violence upon others: A judge articulates herunderstanding of a text, and as a result, somebody loses his freedom, his property, his children, even his life." Robert M. Cover, Violence and the Word, 95 YALE L.J. 1601, 1601 (1986).

29. See, e.g., Daniel M. Filler, Random Violence and the Transformation of the Juvenile Justice Debate, 86 VA. L. REV. 1095, 1109-16 (2000) (discussing the role of activist, media, and legislative rhetoric in transforming juvenile justice debate into a campaign for gun control).

30. See, e.g., Martha C. Nussbaum, Poets as Judges: Judicial Rhetoric and the Literary Imagination, 62 U. CHI. L. REV. 1477 (1995); David Ray Papke \& Kathleen H. McManus, Narrative and the Appellate Opinion, 23 LEGAL STUD. F. 449 (1999); Richard A. Posner, Judges' Writing Styles (and Do They Matter?), 62 U. CHI. L. REV. 1421 (1995); Frederick Schauer, Opinions as Rules, 62 U. CHI. L. REV. 1455 (1995); Patricia M. Wald, The Rhetoric of Results and the Results of Rhetoric: Judicial Writings, 62 U. CHI. L. REV. 1371 (1995); Wetlaufer, supra note 26, at 1560-64; James Boyd White, What's an Opinion For?, 62 U. CHI. L. REV. 1363 (1995). 
rhetoric. ${ }^{31}$ Law and economics scholars have begun to acknowledge the important role of rhetoric in shaping the behavior of "rational actors." 32 Not surprisingly, legal scholars have even turned a light on their own work. A remarkable body of literature has developed on the use of storytelling in legal scholarship. ${ }^{33}$ Narrative scholars offer first person stories ${ }^{34}$ hypothetical stories,${ }^{35}$ dialogues, ${ }^{36}$ and even fictional reworkings of real cases. ${ }^{37}$ Eventually, even the tax scholars became storytellers. ${ }^{38}$ Legal commentators have formed an intellectual scrum, brutally debating the virtues and vices of narrative scholarship. ${ }^{39}$

31. See, e.g., Richard K. Sherwin, Law Frames: Historical Truth and Narrative Necessity in a Criminal Case, 47 STAN. L. REV. 39, 45-47 (1994); Wetlaufer, supra note 26 , at $1557-60$.

32. See, e.g., Timur Kuran \& Cass R. Sunstein, Availability Cascades and Risk Regulation, 51 STAN. L. REV. 683, 703-11 (1999) (arguing that because of human cognitive processes, rhetoric can have a powerfuleffect on how individuals perceive and calculate risks).

33. For an important early and legitimizing contribution to this literature, see Symposium, Legal Storytelling, 87 MICH. L. REV. 2073 (1989).

34. See, e.g., BRYAN K. FAIR, Notes of A RACIAL CASTE BABY: COlOR Blindness AND THE END OF AFFIRMATIVE ACTION 1-65 (1997); PATRICIA J. W ILliams, The AlCHEMY OF RACE AND RightS (1991); Marie Ashe, Zig-Zag Stitching and the Seamless Web: Thoughts on "Reproduction" and the Law, 13 NOVA L. REV. 355 (1989); Susan Estrich, Rape, 95 YALE L.J. 1087, 1087-89 (1986).

35. See, e.g., DERRICK A. BELl, AND W E ARE Not SAVED: The Elusive Quest FOR RACIAL JUSTICE (1987); Richard Delgado, Storytelling for Oppositionists and Others: A Plea for Narrative, 87 MICH. L. REV. 2411, 2418-26 (1989) (offering hypothetical story of an African-American lawyer denied law teaching job).

36. See, e.g., Richard Delgado, THE RODRIGo CHRONIClES: CONVERSATIONS A BOUT AMERICA AND RACE (1995).

37. See, e.g., David Dante Troutt, Screws, Koon, and Routine Aberrations: The Use of Fictional Narratives in Federal Police Brutality Prosecutions, 74 N.Y.U. L. REV. 18, 27-52 (1999) (presenting fictional narration of events leading to important police brutality prosecution).

38. See Carolyn C. Jones, Mapping Tax Narratives, 73 TUL. L. REV. 653, 659-63 (1998).

39. Among those supporting narrative scholarship, see, for example, Kathryn Abrams, Hearing the Call of Stories, 79 CAL. L. REV. 971 (1991); Jane B. Baron, Resistance to Stories, 67 S. CAL. L. REV. 255, 279-80 (1994); William N. Eskridge, Jr., Gaylegal Narratives, 46 STAN. L. REV. 607 (1994); George A. Martinez, Philosophical Considerations and the Use of Narrative in Law, 30 RUTGERS L.J. 683 (1999). Examples of articles critical of narrative scholarship include Daniel A. Farber \& Suzanna Sherry, Telling Stories Out of School: An Essay on Legal Narratives, 45 StAN. L. REV. 807 (1993); Mark Tushnet, The Degradation of Constitutional Discourse, 81 GEO. L.J. 251 (1992).

The debate has continued, and even heated up, over time. In 1997, Farber and Sherry published a book crystallizing their critiques of narrative scholarship, and what they termed "radical multiculturalism." DANIEL A. FARBER \& SUZANNA SHERRY, BEYOND ALL REASON: THE RADICAL A SSAULT ON TRUTHINA MERICAN LAW (1997). This book triggered vitriolic criticism from a variety of commentators. Indeed, the Minnesota Law Review dedicated an entire (angry) volume to criticism of this single 
Despite the relentless focus on rhetoric in every nook and cranny of the law, commentators have forgotten the rhetoric of arguably the most important players in the legal production process: legislators, the lawmakers themselves. Scholars have largely ignored the rhetoric of legislative debate. ${ }^{40} \mathrm{It}$ is as if they have failed to notice the central role of statutes in American law.

This gap in the legal literature is quite remarkable. Notwithstanding the importance of judicial and courtroom rhetoric, the rhetoric of legislative debate demands special scrutiny. Legislative debate is a highly public process, concerning public problems, with serious and far-reaching consequences. The study of legislative rhetoric is essential to comprehending what laws we have, why we have them, and how they will be applied in the future. ${ }^{41}$

Legislative debate is a criticalstep in the production of new law. On the one hand, debate offers legislators a chance to show constituents-voters and donors alike-that they are kindred spirits. ${ }^{42}$ In that sense, legislative debate is a mirror of society, a legislator's opportunity to prove she shares prevailing socialvalues. On the other hand, legislative debate is a chance for representatives to transform opinions

book. See generally, Symposium, Essays in Response to Beyond All Reason, 83 MINN. L. REV. 1589 (1999).

40. Although there are no comprehensive studies of the rhetoric of a bill's legislative debate, a few scholars have discussed legislative rhetoric. E.g., Chai R. Feldblum, The Moral Rhetoric ofLegislation, 72 N.Y.U. L.REV. 992 (1997) (recounting subcommittee conversation about morality during consideration of Employment Nondiscrimination Act of 1997); David A. Hyman, Lies, Damned Lies, and Narrative, 73 IND. L.J. 797 (1998) (criticizing role of patient-dumping stories in Congress's adoption of Emergency Medical Treatment and Active Labor Act); J. Christopher Rideout, So What's in a Name?: A Rhetorical Reading of Washington's Sexually Violent Predator's Act, 15 U. PUGET SOUND L. REV. 781 (1991) (discussing rhetoric presented to, and used by, Washington Governor's Task Force on Community Prevention); Charles J. Butler, Note, The Defense of Marriage Act: Congress 's Use of Narrative in the Debate over Same-Sex Marriage, 73 N.Y.U. L. REV. 841 (1998) (discussing use of narrative at various points in legislative history of Defense of Marriage Act). Scholars in disciplines outside law have also looked at legislative rhetoric, although to somewhat different ends. E.g. David Austen-Smith, Information Transmission in Debate, 34 A M. J. POL. SCI. 124 (1990) (studying role of legislative debate on committee decisions); Carrie Crenshaw, Resisting Whiteness' Rhetorical Silence, 61 W .J. COMM. 253 (1997) (analyzing role of whiteness as explicit issue in U.S. Senate debate over reauthorization of United Daughters of the Confederacy insignia patent); Nancy A. Naples, The "New Consensus" on the "Gendered Social Contract”: The 1987-1988 U.S. Congressional Hearings on Welfare Reform, 22 SIGNS 907 (1997) (analyzing "discursive frames" of welfare reform within Congressional hearings).

41. Indeed, scholars debating the appropriate judicial use of legislative history implicitly concede the importance of legis lative rhetoric. Their work has typically focused on the singular problem of divining legislative intent, however, rather than on broader questions about the role and impact of legislative rhetoric.

42. See, e.g., Richard A.Smith,Advocacy, Interpretation, and Influence in the U.S. Congress, 78 AM. POL. SCI. REV. 44, 46 (1984) (arguing that a legislator's public comments are designed to show how a legislator's voting choice is consistent with existing preferences of audiences). 
of others. It is a time to pressure opponents, sway the views of political and media elites, and reach out to the voters, persuading them of a new perspective or explaining an unpopular vote. For some legislators, debate can even be an opportunity for personal testimony. ${ }^{43}$ Debate forms a body of legislative history when courts later interpret the law. ${ }^{44}$ It can create a precedent establishing the parameters of legitimate public discourse. ${ }^{45}$ And it represents a historical text, a form of legislative DNA, a roadmap explaining how and why new law was created. ${ }^{46}$

Some legislative debate is more public than others. U.S. congressional debate is documented in its entirety in the Congressional Record. Once only available to the persistent scholar, or the wealthy LEXIS subscriber, the Congressional Record can now be obtained free on the Internet. ${ }^{47}$ For those with cable television, congressional debate is captured, gavel to gavel, on C-SPAN. ${ }^{48}$ State legislative debate is often a more private affair. For those lacking regular television coverage of legislative proceedings, the best way to learn the content of state legislative debate is to attend in person or read media accounts. While a few states maintain written records of proceedings, in many states debate is preserved only in audio recordings or the memories of those in attendance. Whether debate is broadcast from the nearest television, or burrowed quietly in the chambers of the state house, however, these legislative speeches can tell us a good deal about why we have the laws we have and what these laws mean. ${ }^{49}$

By describing and analyzing the rhetoric of Megan's Law, a simultaneously controversial and unassailable piece of criminal law, ${ }^{50}$ this Article presents the first

43. Assemblyman Spano in the New York Megan's Law debate, for instance, dedicated several minutes to a detailed description of his own childhood abduction at the hands of a man who wanted to make "dirty movies." N.Y. Assembly Minutes of A1059C, at 342-46 (June 28, 1995) [hereinafter N.Y. Assembly] (statement of Mr. Spano) (copy on file with the Indiana Law Journal).

44. For a discussion about the use of legislative debate in judicial interpretation, see infra note 66-69 and accompanying text.

45. In the Clinton impeachment debate, for instance, legislators looked to the Watergate investigation to determine which sorts of claims were "legitimate" bases upon which to argue for impeachment.

46. Although some scholars discount legislative debate, and legislative history generally, for the purposes of judicial interpretation, see infra text accompanying note 66 , the rhetoricalchoices made by legislators nonetheless show us how they sought to publicly frame the new law. That information, in turn, tells us something about both the bill and the society into which the bill was born.

47. The Congressional Record is available from the Library of Congress through THOMAS: Legislative Information on the Internet, at http://thomas.loc.gov (last visited Feb. 9, 2001).

48. Steven Frantzich \& John Sullivan, The C-SPAN Revolution 124 (1996).

49. The meaning of a law is not fixed, of course. A given law may serve different functions and may represent different things to different people. By studying legislative speeches, however, we can discover how legislators may have understood these laws, how courts are likely to apply them, and how society was convinced to accept their adoption.

50. "Criminal law" is used here in its broad sense, including not only criminal offenses and punishments, but also law collaterally regulating offenders. Other good 
comprehensive study of the rhetoric of legislative debate. In doing so, it addresses and begins to fill a troubling hole in the literature of rhetoric and law. At first glance, the Megan's Law debates might not seem a fertile ground for such research. Given the overwhelming legislative support for the laws, the debates might have been short and sterile; after all, few legislators needed convincing. Yet, despite good reasons to expect vapid debates, these legislative discussions proved engaging and controversial. While they were one-sided, similar perhaps to certain other bills expanding criminallaw, ${ }^{51}$ the Megan's Law debates provide an excellent starting point forstudying how legislators talk about new law. One can assume that if these debates provide a rich trove of rhetorical material, other scholars will be spurred to study the debates of more partisan legislation.

This Article chooses two paradigmatic debates forcomparison: legislative disputes in the U.S. Congress and the New York state legislature. ${ }^{52}$ Part I offers a framework for this study. It begins by suggesting several practical purposes served by legislative debate. It then explains the decision to study Congress and the New York debates, setting out the particular laws under consideration. It also describes the structure of debate in these two jurisdictions. Part II then gives the results of the study, providing an extensive description of the Megan's Law legislative debates in both the U.S. Congress and the New York state legislature. It segments the debates into three thematic areas:arguments justifying the need for new sex offender legislation, claims regarding the benefits of Megan's Law, and discussions about problems with the law. Part III analyzes and critiques the debates. It explores the pros and cons of legislators' heavy use of victim narratives. It critiques legislators' use of statistics and suggests that, despite the actual scope of Megan's Law, legislators framed the bill exclusively in terms of child protection. Finally, it discusses legislators' explicit and implicit claims about the bills' demographic impact. Part IV considers whether the rhetoric of Megan's Law served the practical purposes of legislative debate. It suggests that rhetoric may have influenced voting decisions, educated the public both in good and problematic ways, and provided courts useful material for judicial review. Finally, this part offers limited suggestions for improving legislative rhetoric.

examples of formally civil "criminal laws" are qui tam and civil forfeiture actions. Qui tam, or "private attorney general," provisions were created to allow citizen enforcement of criminal law. Harold J. Krent, Executive Control over Criminal Law Enforcement: Some Lessons from History, 38 A M. U. L. REV. 275, 297 (1989). Civil forfeiture provisions allow government seizure "of a man's property by reason of offences committed by him.” Boyd v. United States, 116 U.S. 616, 634 (1886).

51. Some criminallaws, such as those that regulate guns, pollution, and other wellfunded interests, are the subject of significant dispute. Debate about criminal laws dealing with "blue-collar crime" - violence, theft, sex offenses, for example-might be expected to be more one-sided.

52. The legislative debate in the Congress was an example of virtually one-sided dialogue; only one person spoke against any portion of Megan's Law, and even he ultimately voted for it. The debate in New York, while reflecting strong support for the bill, also included substantial and sharp criticism from a small cadre of opponents. For a further discussion of the reasons for studying these two debates, see infra text accompanying note 70 . 


\section{FRAMEWORK FOR THE STUDY}

\section{A. The Practical Purposes of Legislative Debate}

Before beginning the study of legislative rhetoric, it is worth first considering the practical purposes of debate. Although a worthwhile project, this Article does not make claims about the proper role of legislative debate in a democratic representative government. It therefore does not attempt to evaluate whetherthe rhetoric of Megan's Law contributed in a normatively "good" way to the goals of democratic government. Instead, this Article simply posits that, as a practical matter, legislative debate serves at least three purposes.

First, debate can influence legislative voting decisions. Rhetoric influences these decisions directly when it persuades representatives to change their opinion on an issue. Although some scholars have assumed that legislators make up their minds before debate, ${ }^{53}$ others argue that debate can affect the se decisions. ${ }^{54}$ Debatecan also influence votes less directly, even when they do not alter legislators' core beliefs about a bill. Legislators frequently vote based on their self-interested concern for reelection. ${ }^{55}$ When advocates for a popular bill use rhetoric that alerts otherwis e inattentive citizens about the proposal, opponents may recalculate the risks of opposing a bill and thus change their vote. ${ }^{56}$ In Congress particularly, where legislative debates are nationally televised, legislative rhetoric is particularly capable of capturing public attention and captivating voter interest. ${ }^{57}$

Because it is a public process, legislative debate also functions as an educational

53. See, e.g., Ronald D. Elving, Brighter Lights, Wider Windows: Presenting Congress in the 1990s, in CONGRESS, THE PRESS, AND THE PUBLIC 171, 171-74 (Thomas E. Mann \& Norman J. Ornstein eds., 1994) (discussing Congress's history of private deal making and anonymity).

54. See, e.g., Joseph M. Bessette, The Mild Voice of Reason: Deliberate DEMOCRACY AND AMERICAN NATIONAL GOVERNMENT 166 (1997).

55. Many commentators argue that the goal of reelection is the leading force in legislative decisionmaking. See, e.g., Herbert Hovenkamp, Legislation, Well-Being, and Public Choice, 57 U. CHI. L. REV. 63, 88 (1990). Others, however, argue that ideology may trump the desire for reelection, or may shape legislators' understandings of the best way to be reelected. See, e.g., Edward L. Rubin, Beyond Public Choice: Comprehensive Rationality in the Writing and Reading of Statutes, 66 N.Y.U. L. REV. 1, 57 (1991).

56. Political scientist R. Douglas Arnold argues that voters can be divided into "attentive publics" and "inattentive publics." R. DOUGLAS ARNOLD, THE LOGIC OF CONGRESSIONAL ACTION 64-71 (1990). Arnold argues that legislators "feel electorally pressured to serve inattentive citizens only if an issue is salient or potentially salient to substantial numbers of those citizens." $I d$. at 128 . Legislators must therefore watch debate carefully to see if it is likely to activate these otherwise inattentive citizens. Arnold contends that congressionalleaders can use public procedures, like legislative debate, to force legislators to "stand up and be counted." Id. at 130.

57. See infra note 62 and accompanying text. Arguably, C-SPAN viewers are the public segment least likely to have been inattentive in the first place. Studies show they are a particularly politically engaged group. See infra note 62. 
tool. Both the media and individual citizens look to legislators as a source of information; ${ }^{58}$ legislators are, after all, elected to do the grunt work of policy analysis. ${ }^{59}$ Reporters, for instance, frequently cite legislators' comments uncritically. The advent of C-SPAN has radically expanded the educative function of congressional debate. C-SPAN promotes public education three ways. First, political and media elite rely on C-SPAN as an informational source. ${ }^{60}$ Second, the media uses C-SPAN as a provider of news content. ${ }^{61}$ Third, a surprising number of politically engaged voters watch CSPAN directly. ${ }^{62}$ Legislative debate is an opportunity for representatives to both inform the media and the public, and to shape public opinion. ${ }^{63}$ Legislators in both

58. See KATHERINe BecketT, MAKING CRIME PAY: LAW AND ORder IN CONTEMPORARY A MERICAN POLITICS 77 (1997) (indicating that crime news stories rely heavily on "official sources"); JOEL BEST, THREATENED CHILDREN: RHETORIC AND CONCERN ABOUT CHILD VICTIMS 89, 95 (1990) (noting that the press relies on comments of political leaders and showing example of legislative floor speech used as a news peg).

59. See N.Y. Assembly, supra note 43, at 312-13 (statement of Ms. John).

60. C-SPAN is watched by disproportionate numbers of state-level politicians and government officials, CEO's, and newspaper editors. Not only do these influential individuals watch C-SPAN, providing a particularly influential target population for legislative floor speeches, a remarkable thirty-three percent of this group "credit CSPAN with causing them to change their minds on a public issue." FRANTZICH \& SULLIVAN, supra note 48, at 243-44. Frantzich and Sullivan also found that "journalists report an increasing use of C-SPAN for monitoring the political process." Id. at 243.

61. C-SPAN permits the media to use up to three minutes of television coverage for free.Hoping to take advantage of free press during the evening news, legislators will contact local media to let them know when they are scheduled to make floor speeches. Id. at 46 . Not surprisingly, local stations take advantage of the free material, and show C-SPAN clips on their news programs. Forrest Maltzman \& Lee Sigelman, The Politics ofTalk:Unconstrained Floor Time in the U.S. House of Representatives, 58 J. POL. 819, 820 (1996).

62. Brian Lamb, the creator of C-SPAN and current Chairman and CEO, estimated that the viewership of the network is typically between 50,000 and 100,000; however, at peak times, it can reach about three million. FRANTZICH \& SULLIVAN, supra note 48, at 226-28. Viewership is relatively broad. A 1994 survey showed that " $8.6 \%$ of the U.S. population had watched C-SPAN 'during the lastweek,", and a 1992 study indicated that the average viewer who watched C-SPAN watched it for twenty-one hours per month. Id.

The most remarkable aspect of the C-SPAN viewership is its level of political engagement.In The C-SPAN Revolution, Frantzich and Sullivan suggest that C-SPAN viewers vote much more frequently than the rest of America; they indicate that these viewers vote "at rates 25-35 percentage points above the national averages in both presidential and off year elections." Id. at 236. In fact, even this estimate may be conservative; a 1988 University of Maryland survey showed that " $84 \%$ of C-SPAN viewers were registered to vote" and, of these, 92\% actually voted. Id. at 234, 236.

63. See 142 CONG. REC. 17,114 (1996) (statement of Rep. Dornan) (recommending that viewers obtain an informative magazine article). 
Congress ${ }^{64}$ and New York ${ }^{65}$ made statements expressly reflecting this objective.

Finally, legislative debate helps courts interpret new law. When the meaning of a law is not apparent, and sometimes even when it is, courts look to legislative history as an interpretive tool. Although some commentators, and two Supreme Court justices, rail against the widespread use of legislative history, ${ }^{66}$ courts routinely rely on these materials in their analyses ${ }^{67}$ At times, courts use this rhetoric as legislators intend, adopting the meaning articulated by bills' supporters ${ }^{68}$ Othertimes, though, courts may use supporters' rhetoric to invalidate a law establishing, for instance, that legislators' intentions were impermissible. ${ }^{69}$ However it is ultimately used by courts,

64. Cf. BECKETT, supra note 58, at 24-25 (concluding that public fears about crime are shaped more by comments of political leaders than actual crime rates).

65. See, e.g., N.Y. Assembly, supra note 43, at 395 (statement of Ms. Katz) (warning listeners that bill will not be panacea).

66. Justice Scalia, for instance, argues that reliance on legislative history is almost always improper. E.g., Bank One Chicago v. Midwest Bank \& Trust Co., 516 U.S. 264, 279-83 (1996) (Scalia, J., concurring in part) (making the case against interpretation with legislative history). For a more thorough discussion of what he terms this "new textualism," see William N. Eskridge, Jr., The New Textualism, 37 UCLA L. REV. 621 (1990). Others argue that use of such legislative materials is wholly appropriate. E.g., Stephen Breyer, On the Uses of Legislative History in Interpreting Statutes, 65 S. CAL. L. REV. 845 (1992).

67. Indeed, a trial court—though later reversed-relied on New York's legislative debates to strike down New York's Megan's Law. Doe v. Pataki, 940 F. Supp.603, 62122 (S.D.N.Y. 1996), rev'd in relevant part, 120 F.3d 1263 (2d Cir. 1997).

A majority of the Supreme Court relies upon legislative materials to interpret statutes. See, e.g., Holloway v. United States, 526 U.S. 1, 9(1999)(using congressional floor speeches to interpret meaning of federalcarjacking statute). Some commentators criticize legislative debate as a less reliable form of legislative history. See W ILLIAM N. ESKRIDGE, JR. ET AL., LEGISLATION AND STATUTORY INTERPRETATION 304 (2000) (arguing that courts are more likely to rely only on committee reports and statements of supporters because "[t]here is less reason to think that ... [other legislative] material reflects the views of the enacting coalition and more reason to worry that it might have been strategically planted in the record"). Nonetheless, many courts rely on these sorts of floor remarks when interpreting statutes. E.g., Holloway, 526 U.S. at 9 n.7 (relying on remarks of two supporters of carjacking bill to prove law's "broad deterrent purpose"); In re G.O., 710 N.E.2d 140, 144, 146 (Ill. App. Ct. 1999) (interpreting intent of juvenile justice statute through extensive citation to state legislative debate); Dillehey v. Texas, 815 S.W.2d 623, 624-26 (Tex. Crim. App. 1991) (citing text of the legislative debate and claiming that the court has long honored "as binding evidence of legislative intent, bill analyses and study group reports and legislative council reports and floor debate"); see also United Steelworkers v. Weber, 443 U.S. 193 (1979) (citing, in both majority and dissent, comments from a variety of different legislators).

68. See, e.g., Holloway, 526 U.S. at 9.

69. The Supreme Court has held that statements by legislators are particularly valuable for establishing a legislature's discriminatory intent. Arlington Heights v. Metro. Hous. Dev. Corp., 429 U.S. 252, 268 (1977); cf. Church of the Lukumi Babalu Aye, Inc. v. City of Hialeah, 508 U.S. 520 (1993) (relying in part on city council speeches to strike down regulation on Santeria practice); Hunter v. Underwood, 471 
legislative rhetoric influences the subsequent application and interpretation of new law.

\section{B. The Laws Under Study}

This Article presents a study of both federal and state debate.$^{70}$ Federaldebate was chosen because it may reflect broad, national themes. Also, members of Congress maintain a national profile and are more likely to provide both policy and rhetorical cues to state legislators. Because most criminallaw is created and enforced by states, however, and because the federal Megan's Law was principally a mandate for state action, it seemed essential to study some state level debate. The New York debate served as a good counterpoint to the federal dialogue. First, unlike some state legislatures, New York representatives bothered to debate the merits of the bill. In addition, because of New York's political diversity, a small cadre of vocal opponents staked out rhetorical positions again st the bill. ${ }^{71}$ Finally, the two jurisdictions featured structurally dissimilar debates. ${ }^{72}$

For ease of explanation, this Article frequently refers to the "federal Megan's Law" and "New York's Megan's Law." In fact, the federal Megan's Law is really a set of three laws passed at different times. ${ }^{73}$ In 1994, Congress considered and passed the Jacob Wetterling Crimes AgainstChildren and Sexually ViolentOffenders Registration

U.S. 222, 228-29 (1985) (citing statements at Alabama constitutional convention to establish racially neutral law was motivated by racial animus).

70. This study relied entirely on written transcripts of both the federal and New York debates. Compared to the New York debates, congressional debate, documented in the Congressional Record, was easy to secure. State legislative debate is often more difficult to exhume, but transcripts of the New York debate were obtained upon written request. The decision to make use of written transcripts is not necessarily without consequence. First, there is a risk of inaccurate documentation. Studies have shown that the Congressional Record is, in the main, accurate. See J.A. Hendrix, $A$ New Look at the Textual Authenticity of Speeches in the Congressional Record, 31 S. SPEECH J. 153, 159 (1965). The accuracy of New York's transcription, on the other hand, is not known. Nonetheless, because this study does not focus on microscopic aspects of rhetoric — verb choice, forinstance, or the use of alliteration-it is unlikely that transcription errors would alter this Article's conclusions. A second drawback to reliance on a written record is that important aspects of oratory, such as tone and cadence, are lost. Although this infirmity limits, to some extent, the scope of this Article, it again seems unlikely that the absence of this detail would alter any of the broader conclusions here. In the next section, then, this Article sets out the results of the study; it provides an account of the Megan's Law debate as it unfolded in each of these two jurisdictions.

71. See infra text accompanying notes 190-206.

72. See infra text accompanying notes 190-206.

73. The decision to refer to theselaws as "Megan's Laws" within the text of this Article reflects a decision to allow the powerful story of Megan Kanka to inform every reference to these provisions. It was a practical decision, one designed to aid a reader's understanding of this piece. This footnote is designed, however, to alert readers to the potential emotional impact of this editorial choice. 
Act ("Wetterling Act"). ${ }^{74}$ This provision compelled states ${ }^{75}$ to register offenders convicted of a wide range of sexual offenses, regardless of the age of the victims, as well as those convicted of certain nonsexual offenses against children, including nonparental kidnapping and false imprisonment. ${ }^{76}$ Two years later, Congress adopted two additional laws involving these offenders. The first, actually entitled Megan's Law ${ }^{77}$ required states to adopt some form of community notification for those offenders already covered by the Wetterling Act. ${ }^{78}$ The second, called the Pam Lyncher Sexual Offender Tracking and Identification Act of $1996,{ }^{79}$ created a federal database containing this registration data. ${ }^{80}$

The New York law, officially titled the Sex OffenderRegistration Act, ${ }^{81}$ was a single comprehensive bill requiring certain individuals to register, mandating that the state categorize these individuals into groups based on their danger to the community and authorizing varying types of community notification based on their riskgroup. ${ }^{82}$ The law applied to offenders convicted of a host of sexual offenses committed against children, ranging from forcible rape to consensual sex with a minor to possession of child pornography. ${ }^{83}$ Like the federal law, it also covered individuals convicted of kidnapping or unlawful imprisonment of child victims, so long as the offender was not a parent ${ }^{84}$ and offenders convicted of forcible sexualoffenses against people of any age. ${ }^{85}$

\section{The Structure of the Debates}

The structures of the federal and New York debates differed. Congressionaldebate can be an extended and diffuse process. In some ways, the term "debate" is a misnomer, because the discussion of new law can occur during designated debates as well as in supplemental periods set aside for speeches on any topic. ${ }^{86}$ Debate about

74. Jacob Wetterling Crimes Against Children and Sexually Violent Offenders Registration Act, Pub. L. No. 103-322, 108 Stat. 2038 (1994) (codified as amended at 42 U.S.C. § 14071 (1994 \& Supp. IV 1998)).

75. Failure to comply with this regulation would have subjected a state to criminaljustice-funding cuts. $I d$.

76. The exclusion of parental kidnapping and false imprisonment probably was an acknowledgment of the complicated motivations that might cause a noncustodial parent to take physical custody of her child.

77. Megan's Law, Pub. L. No. 104-145, 110 Stat. 1345 (1996) (amending 42 U.S.C. $\S 14071(d)(1994))$.

78. 42 U.S.C. § 14071(d) (1994).

79. Lyncher Sexual Offender Tracking and Identification Act of 1996, Pub. L. No. 104-236, 110 Stat. 3093 (codified as amended at 42 U.S.C. $\$ 14072$ (Supp. IV 1998)).

80. 42 U.S.C. $\$ 14072$ (Supp. IV 1998).

81. N.Y. CORRECT. LAW § 168 (McKinney Supp. 1999).

82. Id.

83. Id. $\S 168-192$

84. Id.

85. Id.

86. The House, for instance, provides for one- and five-minute speeches and "extended remarks," allowing opportunities for legislators to speak out publicly on any topic they choose. Forrest Maltzman \& Lee Sigelman, The Politics of Talk: 
the Wetterling Act was further complicated by the fact that discussion of the provision was intermingled with conversation about other portions of the overarching crime bill, the Violent Crime Control and Law Enforcement Act of 1994. ${ }^{87}$ Floor debate over registration began in early 1993, and ended upon the bill's passage in August $1994{ }^{88}$ Discussion about extending the Wetterling Act to include community notification began in mid-1994 and continued until passage of Megan's Law in 1996. ${ }^{89}$ As is common in congressional debate, where representatives often prepare their statements in advance, speeches did not typically address each other in a back and forth fashion. In any case, there was minimal disagreement. Only one legislator, Representative Watt of North Carolina, spoke out against any of the bills, openly opposing both 1996 provisions. ${ }^{90}$ The lack of conflict did not silence supporters of these laws, however. Quite the contrary, many congressmen and senators spoke out on the bills, often with passion and even vitriol.

In New York, on the other hand, the debate was more focused. In both the Assembly and the Senate, legislators homed in on this single piece of legislation during a single day. The New York debate featured far more conflict than in Congress. Although the billpassed overwhelmingly, ${ }^{91}$ several assemblymen and senators voiced disapproval of the legislation and supporters responded with their own impassioned appeals. Unlike the congressional debate, legislators' comments appeared to be

Unconstrained Floor Time in the U.S. House of Representatives, 58 J. POL. 819, 819 (1996); see also Committee on Rules, U.S. House of Representatives, Floor Procedure in the U.S. House of Representatives, at http://www.house.gov/rules/floor_man.htm (last visited Jan. 9, 2001). These types of speeches were included within the debate studied here.

87. Violent Crime Control and Law Enforcement Act of 1994, Pub. L. No. 103-322, 108 Stat. 1796 (codified at 42 U.S.C. $§ 13701$ (1994)).

88. The firstfloor discussion of registration came in the context of the freestanding Jacob Wetterling Crimes Against Children Act, H.R. REP.No.103-324(1993), reprinted in 1994 U.S.C.C.A.N. 1801. E.g., 139 CONG. REC. 10,998 (1993) (statement of Rep. Ramstad). The Wetterling Act was ultimately incorporated into the Violent Crime Control and Law Enforcement Act, and debate continued until August 25, 1994, the date that the Senate agreed to the conference report of the bill. E.g., 140 CONG. REC. 24,005-06 (1994) (statement of Sen. Lautenberg).

89. Initial discussion about community notification occurred during consideration of the more limited Wetterling Act. E.g., 140 CONG. REC. 10,638 (1994) (statement of Sen. Gorton) (arguing in favor of S.2363, a bill that would have required states to create both registration and notification procedures). Debate continued until May 7 , 1996, two days before the bill passed.E.g., 142 CONG. REC. 10,313 (1996) (statement of Rep. Jackson-Lee). Indeed, discussion of these sex-offense issues continued until adoption of the Lyncher Act on September 26, 1996. E.g., 142 CONG. REC. H11,133 (daily ed. Sept. 25, 1996) (statement of Rep. Zimmer).

90. See infra text accompanying note 177. Ironically, Representative Watt must have been sufficiently concerned about the political consequences of opposing this legislation that, despite his public complaints on the House floor, including a claim that the bill was "un-American," Watt ultimately voted in favor of the legislation. See infra text accompanying note 181 .

91. The final New York Senate tally was 54 to 1; in the Assembly, supporters prevailed 140 to 9 . 
improvised and legislators actually addressed one another.

Despite differences between the bills, and the structure of debate, the substantive discussions about Megan's Law were comparable. Both included extended debate about the need for new law and both focused on the registration and notification provisions themselves, rather than upon concerns about the appropriate role of state versus federal intervention. ${ }^{92}$ A comparison of the two debates proved workable because they did in fact cover much common ground, and because New York's law was very similar to the minimum law mandated by the federal Megan's Law.

\section{A DESCRIPTIVE ACCOUNT OF THE MEGAN'S LAW LEGISLATIVE DEBATES}

Legislative debates do not flow like well crafted narrative. Instead, they are a sprawling series of individual speeches which are best studied as an organic whole. Short of replicating the complete debates, any description of them necessarily will be reductive. This Part divides the debates into three thematic groups: arguments justifying the need for new sex-offender laws, claims about the anticipated benefits of Megan's Law, and discussions about possible drawbacks to the proposal. Federal and New York legislative rhetoric is presented side by side within each thematic group to allow for easy comparison.

\section{A. Justification for New Legislation}

This section outlines legislators' claims about the need for new sex-offender regulations ${ }^{93}$ Legislators offered three types of arguments to explain their support for Megan's Law. First, they told anecdotal stories of child victimization. Second, they provided a variety of statistics designed to show the extent and intractability of the sex-offender problem. Third, they used dehumanizing language to describe these offenders, presumably showing this population's suitability for additional social sanctions.

\section{Anecdotal Narratives}

The single most common rhetorical trope employed in both the federal and New York debates was the citation and description of individual cases of child abduction, sexual abuse, and murder. Again and again, legislators argued the need for new sexoffender legislation by referring, in varying levels of detail, to particularly well-known incidents. Most of these cases had already received substantial national media coverage. ${ }^{94}$

92. Both debates featured some discussion of federalism-related issues. See infra text accompanying notes 186, 197.

93. While the provisions of Megan's Law were not limited to sex offenders, see supra text accompanying note 76 , arguments about the law focused almostexclusively on this population.

94. Articles discussing Megan Kanka included Girl's Killing Sparks Call for New Laws, S.F. EXAMINER, Aug. 3, 1994, at A10, LEXIS, News Library, SFEXAM File; Man Charged in 7-Year-Old Neighbor's Killing, N.Y. TIMES, Aug. 1, 1994, at B5; Anna 
Although both debates relied upon these narratives, U.S. representatives and senators used high-profile stories more consistently than did their New York counterparts. This reliance on stories began at the bills' inceptions; both Jacob Wetterling and Megan Kanka were famous crime victims. ${ }^{95}$ Thus, even the slightest reference to these bills immediately invoked memories of their victimization. Legislators discussed these brutal stories again and again, sometimes in graphic detail. Representative Zimmer, for instance, provided a heart rending description of the Megan Kanka case:

[O]n July 29, 1994, a beautiful little girl named Megan Kanka was lured into the home of a man who literally lived across the street from her. He said that he had a puppy he wanted to show her. He then proceeded to brutally rape and murder this little girl. ${ }^{96}$

A few minutes later, Representative Jackson-Lee reminded listeners that the bill was named after "Megan Kanka, who was raped and strangled and murdered by a twice-

Quindlen, So What if Law Isn't Fair to Sex Offenders? Children Come First, CHI. TRIB., Aug. 8, 1994, at 13. Coverage of the Polly Klaas incident included Michelle Locke, Paroled Kidnapper Held in California Girl's Abduction, CHI. SUN-TIMES, Dec. 2, 1993, at 56, LEXIS, News Library, CHISUN File; Richard C. Paddock, All-Out Search for Missing Girl, L.A. TIMES, Oct. 6, 1993, at A3; Witnesses Identify Suspect in California Girl's Abduction, ATL. J.-CONST., Dec. 3, 1993, at A4, LEXIS, News Library, ATLJNLFile. Stories about Amber Hagerman included Search for Girl Ends, CHI. TRIB., Jan. 18, 1996 (Evening Update ed.), at 2, LEXIS, News Library, CHTRIB File; Shannon Tangonan, “Brutal”" End to Kidnapping, USA TODAY, Jan. 19, 1996, at 3A, LEXIS, News Library, USATDY File. Articles about Ashley Estell included Kevin Caston, Searchers Find Body of Child, DALlAS MORNING NEws, Sept. 6, 1993, at 1A, LEXIS, News Library, DALNWS File; Child Molester Is Charged in Killing, S.F. EXAMINER, Sept. 16, 1993, at A6, LEXIS, News Library, SFEXAM File.

95. According to news accounts, Jacob Wetterling,ten, was abducted at gunpoint by a masked man on October 22, 1989. After One Week, No Kidnap Clues, CHI. TRIB., Oct. 29, 1989, at 16. He had been walking with his brother and another friend in their small town, St. Josephs, Minnesota.Id. The perpetrator allegedly fled with Wetterling on foot. He has never been found. Id.

Megan Kanka, a seven year old, was invited to the home of her neighbor, Jesse Timmendequas, to look at his puppy. Dale Russakoff, Case Driving 'Megan's Law' Results in Murder Conviction: Jury to Decide Whether to Seek Execution, W ASH. Post, May 31, 1997, at A1. There, according to the evidence at trial, he raped and murdered her. Id. According to initial press accounts, neither Richard and Maureen Kanka-Megan's parents-nor the rest of the neighborhood was aware that Timmendequas, and his housemates, had previously been convicted of sexual offenses. Anna Quindlen, Editorial, The Passion to Keep Them Safe, N.Y. TIMES, Aug. 6,1994 , at 19. Later accounts cast doubt on the veracity of this claim. See infra text accompanying notes 246-49. The third federal law was named after Pam Lyncher, a Texas anticrime activist killed in a plane crash.Prison May Be Named After Lyncher, DALLAS MORNING NEWS, July 27, 1996, at 22A (describing Lyncher as a victims'-rights leader), LEXIS, News Library, DALNWS File.

96. 142 CONG. REC. 10,311 (1996) (statement of Rep. Zimmer). 
convicted pedophile who lived across the street from her." 97 These instances reflect only a small number of the references to Megan Kanka. The story of Megan Kanka was mentioned repeatedly. ${ }^{98}$

Legislators told stories of other children as well. Representative Upton offered an account of an interstate kidnapping:

Mr. Speaker, last yearI had two little boys, sons of migrant workers from Texas, in my district who were stolen allegedly by a sexual molester... out from Iowa, picked them up in the twin cities in Michigan; and thank goodness, because it was a nationwide case and CNN and ABC News and "Good Morning America" had his picture, they found him in New Orleans. .9

Othercases were described in fargreater detail. There was the matter of Polly Klaas, for instance, from California. Senator Feinstein explained that "[m]any people throughout our Nation have come to know about this 12-year-old girl from Petaluma, CA, a small, close-knit community north of San Francisco" who had been "kidnapped from her bedroom on October 1, 1993, by a bearded, knife-wielding man who tied her up and threatened to slit her friends' throats as her mother slept in a nearby room. . .. [The assailant] fled with Polly," who was later found dead ${ }^{100}$ She added additional evocative detail. Klaas's body was: “dumped beside a highway. Next to Polly's body police found a specialty condom identical to one [the assailant] had bought at the adult novelty store Seductions a day or two before the kidnapping, according to the store's former owner. Polly's clothes were pushed up to her waist." 101 Fein stein immediately followed Polly's story with the tale of another child victim:

The second little girl I want to tell you about, Amber Hagerman, was visiting her grandparents on January 13 of this year, the day she was kidnapped. An eyewitness later told police that he saw a white or Hispanic man pull the child from her pink tricycle and drag her into a black pickup truck. She was found dead 4 days later-her clothes stolen from her lifeless little body-in a creek behind an apartment complex. ${ }^{102}$

Even more than Representatives Zimmer and Upton, Feinstein told stories that were palpable, easy to visualize, and difficult to forget. ${ }^{103}$

One of the more interesting and elaborate narratives was presented by Senator Gramm of Texas, describing an incident from his home state:

97. Id. at 10,313 (statement of Rep. Jackson-Lee).

98. E.g., id. at 10,664-65 (statement of Sen. Gorton); id. at 10,312 (statement of Rep. Smith); id. at 10,361 (statement of Rep. Fox).

99. Id. at 10,315 (statement of Rep. Upton).

100. Id. at 18,764 (statement of Sen. Feinstein).

101. Id.

102. $I d$.

103. Moments later, Senator Hutchison also mentioned the Hagerman story, saying that "[s]he was kept alive for at least 48 hours before being murdered. Her nude, slashed body was found in a creek bed ...." Id. at 18,765 (statement of Sen. Hutchison). 
Three years ago, a 7-year-old girl named Ashley Estell went to a park in Plano, TX, which is an upscale suburb of Dallas, one of the finest communities in America, and certainly we would assume one of the safest. She went to the park that day to watch her brother play soccer. Ashley's brother played in the second of three games to be played that day and while her parents stayed to watch the final game, Ashley went to play on a swing set. Although there were 2,000 people in the park that day, this little girl was, nevertheless, abducted, raped and brutally murdered.

... The FBI, using the 14 tapes that were turned in [by people who had been videotaping games on the playground], was able to go back and identify a known sexual predator who had been there the day Ashley was abducted ....

What shocked Plano, the whole metroplex and, to some degree, the entire country, was not just this tragic crime, but the fact that the FBI . . .identified not one but two sexual predators who were in the park on that day. It turned out that the referee of all three soccer games played that day was a convicted sexual predator, who had fled from North Carolina to Texas to avoid being sent to prison for 10 years..$^{104}$

Every congressional story told in support of Megan's Law featured a child victim who suffered serious abuse. Legislators did not tell any stories involving arguably less disturbing offenses like consensual sex with minors or possession of child pornography, both of which fell within the ambit of Megan's Law. More importantly, legislators eschewed accounts featuring adult victims. They focused only on vivid, dramatic, and undeniable cases of child victimization.

Stories of child victimization were somewhat less common in the New York debates. Unlike the federal discussions, where legislators dedicated much, if not all, of their commentary to the mention, or graphic description, of individual victim stories, state legislators used storytelling more sparingly. ${ }^{105}$

Interestingly, the story of Megan Kanka's abduction itself was not featured prominently within the New York debate. The Kanka case was mentioned, to be sure. Maureen Kanka was present during the Senate debate, ${ }^{106}$ placing Megan's murder silently, but powerfully, at the center of discussion. The New York bill was explicitly tied to the Kanka murder. Senator Skelos explained, for instance, that " $[\mathrm{t}]$ he purpose for this [bill] is to avoid the Megan Kanka tragedy that we saw in New Jersey." 107 Legislators also linked the New York law to other registration and notification laws bearing Megan's name. ${ }^{108}$ In the main, however, legislators relied upon New York stories, tales of local child victims, and abusers.

One narrative New York legislators mentioned on severaloccasions involved a girl from Binghamton, New York. "Sherry Lindsay, who was the daughter of ... a retired Binghamton police officer... was lured into the house of a convicted sex offender

104. Id. at 7747 (statement of Sen. Gramm).

105. Indeed one legislator, Senator Leichter, expressly cautioned about excessive reliance on the emotionally powerful Megan Kanka story to the exclusion of logic and reason. See N.Y. Senate Minutes of S-11-B, at 6624 (May 24, 1995) [hereinafter N.Y. Senate] (statement of Sen. Leichter) (copy on file with the Indiana Law Journal).

106. See id. at 6583 (statement of Sen. Rath).

107. Id. at 6571 (statement of Sen. Skelos).

108. See, e.g., id. at 6565 (statement of Sen. Skelos). 
while ... trying to make a little extra money. She was held in the basement for three days before he finally killed her." 109 Another legislator noted the case of "a little fouryear-old girl that was abducted, raped and murdered. Had this bill been in place before this, maybe her parents wouldn't have let her go to this man's house, to his apartment and see this man." ${ }^{110}$ Perhaps the most detailed child-victim narrative involved a boy named Steven Stayner:

A man walked up to him in a mall with a whole set of papers and said, “Steven, your parents don't love you anymore, they really don't want you to be with them anymore. They are out in the carand they asked me to take you." And he convinced, this pedophile, Steven Stayner to get in the car.

You know what he did ... ? Every 15 minutes he stopped at a pay telephone. Now, Steven Stayner was an intelligent boy. He said, "Steven, can you tell me your telephone number? I want to call your mom and dad and tell them you love them very much and want to be with them."

He stopped at a pay phone for 24 hours every 15 minutes, made believe he was dialing Steven Stayner's telephone number-really didn't-he hung up, "Mr. and Mrs. Stayner, he loves you very much, he doesn't know why you filed those papers in court. Would you please take-" "Steven, your parents hung up. They really don't want you back. They want you to stay with me. They don't want you to be back with them, they want you to stay with me."

He did that for 24 hours to a five-year-old boy every 15 minutes, and you know what? Steven Stayner stayed with that man for seven years.

They moved to a school district an hour and a half from his original school district. Steven made excuses why his mother wasn't there, his father had died and his mother died and his father got another job because he believed that this pedophile who had abused him for seven years, convinced him that his parents didn't love him anymore. ${ }^{111}$

While child-victim stories were a prominent feature of the New York debate, they were notably lacking in the visual detail evident in the federal debate. Legislators offered fewer physical descriptions and graphic details that might have added to the richness of the narratives. In addition, other than the Stayner story, legislators told terse narratives, sometimes even withholding a victim's name. The Staynercase was quite memorable for its detail, but the detail did not involve the child's physical victimization; that element was underemphasized.

The New York debate also featured a different variation on the child-victim narrative: a firstperson account. Assemblyman Spano told his own personal story of childhood abduction, explaining that "I think it's very important that the Legislators here and the people of this State see and feel through the eyes of a 12-year old the pain and suffering that I went through." 112 He proceeded, over the course of six transcribed pages, to describe how, on his way to purchase milk:

109. Id. at 6620 (statement of Sen. Skelos); see also id. at 6645 (statement of Sen. Libous) (referring to "a young lady from Binghamton who was raped and murdered"). 110. N.Y. Assembly, supra note 43, at 394 (statement of Mr. Warner).

111. Id. at 324-25 (statement of Mr. Tedisco).

112. Id. at 341 (statement of Mr. Spano). 
[A man] walked by me and said, "Do you have a cigarette?" And I said, "No." And he walked on past me and I was paying attention to whatever I was doing and he had walked up into the woods. When I walked past those woods, he grabbed me and pulled me into the woods and it continued from that point. ${ }^{113}$

Spano explained that during the two or three hours he was with this man, the man tried to do "certain things that are better off just not announced here." ${ }^{114}$ He recounted his own careful and successful efforts to convince the man that his family expected him home; Spano also told of convincing the abductor he would voluntarily return the next day. ${ }^{115}$ He then detailed the police's fumbled attempts to arrest the man. According to this account, the perpetrator was finally caught, but ultimately let go for lack of proof. ${ }^{116}$

Spano's story was notable for its restraint. He specifically declined to detail what acts the man attempted to perform, though he stated that he was not raped or sodomized. He also did not discuss the identity of the man, where he lived, what he looked like, and whether he had any prior record. Oddly, despite his stated justification for telling this story, the narrative did not feature Spano's fear and suffering to any great extent. It was, instead, a story of two people locked in a mental battle. The power of Spano's story lay not in its detail, or its horror, but rather in the very fact that a fellow legislator was exposing himself, offering an intimate account of victimization. One can imagine that the chamber fell silent as members listened sympathetically. ${ }^{117}$

The most incongruous child victimization story was told by an opponent of Megan's Law. Seeking to establish his credentials as a good, caring father, Assemblyman Sullivan described his daughter's day on the bus:

I understand the emotion. I have daughters. I understand the emotion that goes through people's minds. My daughter one time couldn't reach the rope on the bus and the bus driver wouldn't stop the bus and took her about a mile away from her home and made her walk back. I went down to the bus garage and thank God they wouldn't tell me who that man was or I wouldn't be here today, I would be in a jail somewhere. ${ }^{118}$

As this narrative reflects, countering powerful stories of abuse can be difficult. Stacked up against the horrors set out by some of his colleagues, Sullivan's tale read as parody.

New York legislators told other stories that did not involve victimization. On multiple occasions, legislators spun idyllic tales of a simpler and safer life. Senator Marcellino waxed nostalgic:

113. $I d$. at 342 .

114. Id. at 343 .

115. Id.

116. Id. at 346 .

117. Because this study was based on a transcribed record, the actual response of fellow legislators cannot be established. This shortfall evidences some costs associated with studying legislative rhetoric in its written form.

118. Id. at 294 (statement of Mr. Sullivan). 
I remember a time when [parents] could allow [their children] to play in the front of their house in the front yard and feel free. I remember a time when you could allow your child to walk to school or walk to the local playground and not wo rry about it. I remember a time when we didn't need to lock fences and lock our gates and lock our doors to our homes. I remember a time when we didn't need burglar alarms in our homes. ${ }^{119}$

Assemblyman Robach recalled that "[w]hen I was a child . . . I went out all day, grabbed my bike, my ball and glove, and was gone pretty much all day in our neighborhood and people knew that it was safe." ${ }^{120}$ Senator Jones "lived in a home a block and a half from a lovely lake in Rochester and a beach that my four children walked to almost daily once they learned to swim, not always with their mother because there were always neighborhood people there." ${ }^{121}$ These were first-person narratives, sepia-toned memories of a time gone by. Ironically, in the New York debate, these nostalgic stories were more detailed and visually complete than the child-victim stories. Victim narratives were terse, unadorned stories of abuse; stories of the past were florid and sentimental.

\section{Statistical Claims}

Legislatures prominently featured arguments based on numerical, or similarresearchbased evidence, in both the federal and New York Megan's Law debates. In Congress, legislators focused on a variety of disparate statistics to establish the need for new legislation. First, legislators sought to establish that child victimization was a widespread problem. Although legislators proved this principally by anecdotal evidence, several garnished their stories with statistical data. Citing the Children's Trust Fund of Texas, Representative Jackson-Lee asserted that in 1995, over 50,000 Texas children suffered child abuse or neglect. ${ }^{122}$ Focusing on a different sample, Representative Ramstad stated that 114,000 children were the victims of attempted abductions in 1988 and 4600 children actually disappeared. ${ }^{123}$ Senator Hutchison of Texas claimed that "[t]wenty percent of those in State prisons convicted of violent crimes-65,000 people-report having victimized a child." 124

In addition to establishing the scope of the current crisis, legislators explained that sexoffenders were a particularly problematic group. Forinstance, both Representative Dunn and Representative McCollum suggested that research proved sex offenders had a higher rate of recidivism than the population at large. These legislators did not offer specific statistics or source cites for their claims. Instead, they couched these arguments in broader, rhetorical terms. Dunn, for instance, argued that " $[t]$ he rate of recidivism for these crimes is astronomical because these people are compulsive." 125

119. N.Y. Senate, supra note 105, at 6586 (statement of Sen. Marcellino).

120. N.Y. Assembly, supra note 43, at 370 (statement of Mr. Robach).

121. N.Y. Senate, supra note 105, at 6659-60 (statement of Sen. Jones).

122. 142 CONG. REC. 10,313 (1996) (statement of Rep. Jackson-Lee).

123. 139 CONG. REC. 31,251 (1993) (statement of Rep. Ramstad).

124. 142 CONG. REC. 18,765-66 (1996) (statement of Sen. Hutchison).

125. 140 CONG. REC. 22,520 (1994) (statement of Rep. Dunn) (referring apparently to "sexual predators" generally). 
Similarly, McCollumargued that "history shows us that people who commit the se kind of crimes are likely to get out of jail and commit them again." ${ }^{126}$ Some legislators offered hard data on recidivism, however. Senator Hutchison stated, for instance, that "we know that more than 40 percent of convicted sex offenders will repeat their crimes." 127

Other legislators focused particularly on child sex offenders. Some spoke of this research generally, explaining that "studies have shown that child sex offenders are some of the most notorious repeat offenders." ${ }^{128}$ Representative Lofgren, a liberal Congres swoman who supported Megan's Law, cited specific research, including a Minnesota study and a California study she herself commissioned, to show that rehabilitation of child sex offenders had a low degree of success. ${ }^{129}$ Representative Ramstad noted that "[a] study of imprisoned child sex offenders found that 74 percent had a previous conviction for another child sex offense" and asserted that a second (also unnamed) study "showed that the average child sex offender molests 117 children." ${ }^{130}$ Senator Gramm compared recidivism rates, arguing that

[t]he probability that someone who is convicted of being a sexual predator, especially if it is a crime against a child, committing that crime again is estimated to be 10 times higher than the probability that an armed robber who is apprehended, convicted, and sent to prison will commit the act of armed robbery again. ${ }^{131}$

Representative Jackson-Lee summarized the data in a particularly appealing soundbite, saying "[i]t is a known fact that the scientific community has concluded that most pedophiles cannot control themselves." 132

126. 142 CONG. REC. H11,134 (daily ed. Sept. 25, 1996) (statement of Rep. McCollum) (referring apparently to sexual offenses generally).

127. 142 CONG. REC. 18,766 (1996) (statement of Sen. Hutchison).

128. 139 CONG. REC. 31,252 (1993) (statement of Rep. Grams). Presumably, Representative Grams was saying that the recidivism rate of child sex offenders is notoriously high. It might be more consistent with the general tone of the debate, with its focus on famous cases, if Grams meant that most notorious repeat criminal offenders are sex offenders.

129. 142 CONG. REC. 10,335 (1996) (statement of Rep. Lofgren).

130. 139 CONG. REC. 31,251 (1993) (statement of Rep.Ramstad). A few minutes after the statement of Representative Ramstad, Representative Fish repeated the same recidivism rate of seventy-four percent. $I d$. at 31,252 (statement of Rep. Fish).

131. 142 CONG. REC. 7748 (1996) (statement of Sen. Gramm).

132. 142 CONG. REC. H11,134 (daily ed. Sept. 25, 1996) (statement of Rep. JacksonLee). Representative Jackson-Lee presumably believed that through hard spiritual work, some pedophiles could control themselves. She stated that the bill would not hurt those who had "made amends, someone who has sought forgiveness and repentance, someone who is born again." Id. Pedophilia is thus treated as a sinful sexualchoice that religion could address. This perspective appears similar to the view of homosexuality held by many modern institutional religious groups. E. g., Jeffrey L. Sheler, Homosexuality Doctrines, U.S. NEWS \& W ORLD REP., July 16, 1990, at 55 (stating that Southern Baptists view homosexuality as a sin, and that homosexuals can "receive forgiveness and victory through personal faith in Jesus Christ"). Not surprisingly, then, one representative explicitly linked pedophilia with male homosexuality. See infra text accompanying note 133. 
The most dramatic statistics were presented by Representative Dornan of California. Rather than using numerical data to show the scope, or intractability, of the child sexual abuse problem, he used numbers to stake out an ideological position about homosexuality:

[T] here is [sic] no heterosexual young men being contacted by women. There are no women predators to speak of .... There is no lesbian, no heterosexual woman who pray [sic] on children. We cannot even find statisticaldata. This is basically a male homosexual problem, and the child molesters of the heterosexual variety are usually drunken disgusting stepfathers who are dismissing their wife and going after her daughter from another marriage. Take out that chunk and take out the numbers and prorate these cohorts, since there is only about three-quarters of a percent of lesbians .... and 1 percent male homosexuals, and the rate of male pedophilia, homosexual pedophilia one makes is 11 to 1 over heterosexual pedophiles. ${ }^{133}$

Dornan made no effort to link these claims to any particularlegislative remedy; he was simply explaining his view of the country's child-molestation problem.

New York legislators also relied on statistics to establish the need for new sexoffender regulations. For instance, New York legislators showed the extent of the existing social crisis by citing rates of child sexual abuse. Senator Paterson asserted that child sexual abuse is estimated to injure as many as one in seven girls and one in twelve boys. ${ }^{134}$ Assemblyman Spano cited statistics from the NationalCenter for Child Abuse and Neglect showing a $286 \%$ increase in the number of sexually abused children between 1980 and $1986 .{ }^{135}$ Similarly, legislators discussed recidivism rates for child sexual offenders. Assemblyman Feldman offered detailed data, for instance, showing a recidivismrate of thirty to forty percent for adults who "molest" boys, and a ten to twenty-nine percent rate for adults who "molest" girls. ${ }^{136}$ He also cited a recidivism rate of from seven to thirty-five percent for those who commit rape. ${ }^{137}$ Another legislatorcited statistics showing that the disproportionately high recidivism rate among pedophiles was because these individuals continued to reoffend even as they aged. ${ }^{138}$

In New York, unlike Congress, legislators openly challenged some of the research offered by Megan's Law proponents. In one case, New York Senator Leichter questioned the pedophile recidivism rate, asking to see the study. ${ }^{139}$ He then pushed one step further, challenging whether the recidivism rate attributed to pedophiles was equally applicable to the many other offenders included within the scope of Megan's Law. ${ }^{140}$ Supporters of the bill were plainly on the defensive with respect to statistical

133. 142 CONG. REC. 17,114 (1996) (statement of Rep. Dornan).

134. N.Y. Senate, supra note 105, at 6573 (statement of Sen. Paterson).

135. N.Y. Assembly, supra note 43, at 347-48 (statement of Mr. Spano).

136. $I d$. at 304 (statement of Mr. Feldman).

137. $I d$.

138. N.Y. Senate, supra note 105, at 6616 (statement of Sen. Skelos) (asserting that forty percent of pedophiles recidivate and that, unlike other offenders, the desire to commit the crime does not diminish with age).

139. See id. at 6616-17 (statement of Sen. Leichter).

140. See id. 
claims. One legislator preempted potentialcriticism of his data, arguing that the recent increase in child assaults was "not just reporting." 141

Perhaps the most powerful critique of proponents' statistics centered on the issue of sexual abuse within families. Not a single Megan's Law supporter cited data that distinguished between familial and nonfamilial abuse. Assemblywoman Clark, herself a supporter of Megan's Law, argued that most abusers would never come within the ambit of the law:

[T] he majority of sexual abuse and assault takes place at the hands of a family member. Yet, the statistics show very, very seldom do you find a family memberconvicted of sexualassault and abuse. Megan's Law is not going to solve this problem. I am very concerned that only a small segment of the population will be affected by this law. ${ }^{142}$

Senator Paterson also addressed this gap, stating that in-home child sexual assault was at least as common as stranger, or neighbor, child sexualassault. ${ }^{143}$ He questioned the extent to which community notification would resolve the widespread familialchild sexual abuse problem. ${ }^{144}$

While statistics and studies were used in both Congress and the New York legislature, the statistics offered in Congress were more diffuse. They related, at times, to sexual assault, child sexual assault, abduction, child abuse, and child victimization generally. The debate in New York featured a heightened focus on statistics relating to child sexual abuse. Legislators overtly challenged the validity of some statistical claims while simultaneously questioning whether the law, as written, was well-suited to resolving the problems evidenced by these numbers.

\section{Devaluation of Offenders}

A third tactic used to justify Megan's Law dealt not with evidence of an existing crisis, but rather with the diminished value of the regulated parties. Legislators made linguistic choices that worked to dehumanize individuals convicted of sexual offenses.

Particularly within the federalcongressionaldebate, legislators repeatedly employed language suggesting that offenders were less worthy of humane treatment. The single most common dehumanizing term used to describe convicted sex offenders was "sexual predators." ${ }^{145}$ It was used as a metaphor, comparing the actions of animals that

141. N.Y. Assembly, supra note 43, at 370 (statement of Mr. Robach). This assertion, backed with no evidence, was notable principally because nobody had suggested that the increase was just reporting.

142. Id. at 398 (statement of Ms. Clark).

143. N.Y. Senate, supra note 105, at 6572-73 (statement of Sen. Paterson).

144. Id. at 6572 .

145. Use of this term is by no means limited to sex offenders. Juvenile delinquents, for instance, are frequently referred to as "superpredators." E.g., PETER ELIKANN, SUPERPREDATORS: THE DEMONIZATION OF OUR CHILDREN B Y THE LAW 10 (1999). Before 1990 , the term "predator," in a sexual sense, was typically found "in the literature of crime fiction and true crime, where it appeared extensively in book titles and blurbs, alongside phrases implying primitivism, animal savagery, and hunting." JENKINS, supra note 21 , at 193-94. 
hunt and kill other animals to sexual offenders' pursuit and sexual victimization of children. $^{146}$

The frequent use of this term was almostinevitable, given the name of one proposed provision. In 1994, Senator Gorton of Washington suggested an alternative to the Wetterling Act requiring states to conduct sex-offender community notification. ${ }^{147}$ Gorton entitled this modification the Sexually Violent Predators Act. ${ }^{148}$ Mere discussion and reference to Gorton's proposal generated multiple references to "sexual predators." ${ }^{149}$ Indeed, use of the term occurred numerous times within the U.S. congressional debate and discussion of the federal Megan's Law. ${ }^{150}$

Other legislators used similarly dehumanizing language. Senator Dole described the man who raped and killed Megan Kanka as "the beast who committed this horrendous crime." ${ }^{151}$ Senator Hutchison called sex offenders "monsters." ${ }^{152}$ Perhaps the most powerfuldehumanizing rhetoric was Representative Schumer's colorfuldescription of the sex offender's ritual: "No matter what we do, the minute they get back on the street, many of them resume their hunt for victims, beginning a restless and unrelenting prowl for children, innocent children to molest, abuse, and in the worst cases to kill." 153 Schumer thus suggested that sexual offenders were wily and dangerous, like wolves.

This tactic of devaluation was less common within the New York debate. Nonetheless, these sorts of terms surfaced on several occasions. ${ }^{154}$ Assemblyman Tedisco, forinstance, declared that "repeat sexualpredators, especially those that prey on children, are the human equivalent of toxic waste." ${ }^{155}$ In a similar, if slightly less hostile vein, Assemblyman Healy implored his colleagues not to "give the protection to the animals, don't give it to the people exploiting children, protect the children." 156

\section{B. Discussion of the Law's Benefits}

146. JENKINS, supra note 21 , at 193.

147. Sexually Violent Predators Act, S. 2363, 103d Cong. (1994).

148. Id.

149. Legislative rhetoric can have consequences that ripple well beyond the legislature itself. For instance, Kansas's decision to name their sexual offender commitment bill the Sexually Violent Predator Act, resulted in the U.S. Supreme Court using the terms "predator" and "predatory" thirty-two times in its review of the law. See Kansas v. Hendricks, 521 U.S. 346 (1997).

150. E.g., 142 CONG. REC. 10,312 (1996) (statement of Rep. Schumer) (declaring that "we need to do all we can to stop these predators"); $i d$. at 7747-48 (statement of Sen. Gramm); 140 CONG. REC. 22,700 (1994) (statement of Sen. Lautenberg).

151. 140 CONG. REC. 21,448 (1994) (statement of Sen. Dole).

152. 142 CONG. REC. 18,766 (1996) (statement of Sen. Hutchison).

153. Id at 10,312 (statement of Rep. Schumer). In a similar vein, Representative McCollum suggested that "sexual predators are remarkably clever and persistently transient." 142 CONG. REC. H11,134 (daily ed. Sept. 25, 1996) (statement of Rep. McCollum).

154. Assemblywoman John offered an example of a kinder, gentler hostility, calling sex offenders "dangerous and terrible people." N.Y. Assembly, supra note 43, at 310 (statement of Ms. John).

155. Id. at 417 (statement of Mr. Tedisco).

156. Id. at 360-61 (statement of Mr. Healey). 
Federallegislators, with their emphasis on the need for new sex-offender regulations, spent relatively little time arguing the virtues of the Megan's Law proposal itself. New York legislators invested somewhat more time focusing on the benefits of the bill. Legislators in both jurisdictions looked primarily at two supposed benefits of the provision: improved child safety and the reclamation of Megan Kanka's life.

\section{Increased Child Safety}

The primary argument offered on behalf of the federal Megan's Law provisions was that it would reduce victimization of children. This claim was hardly surprising since one might expect this to be one chief purpose of the bill. What was remarkable, however, was the way in which legislators sought to prove this claim.

Rather than cite studies or statistics about the efficacy of registration and notification laws, ${ }^{157}$ or a flock of success stories from states that had adopted these laws, federal legislators established the utility of Megan's Law by reference to the Megan Kanka story itself. The most common method for arguing the efficacy of Megan's Law was a single assertion: had the law been in place before Megan Kanka's murder, she would not have been killed. Different legislators expressed varying levels of certitude of this assertion. During the 1994 debates, shortly afterher murder, several legislators, perhaps understanding the seemingly speculative nature of the claim, stated that she might still be alive. ${ }^{158}$ As Senator Biden put it, "had we passed the registry law ... maybe, just maybe, young Megan would be alive today." ${ }^{159}$ Others felt more confident of the legislation's effectiveness, asserting that she would probably still be alive. ${ }^{160}$ Senator Gorton argued, "Had such a [notification] provision been in effect in the State of New Jersey, the recent notorious and terribly regrettable Megan Kanka murder almost certainly would not have taken place." ${ }^{161}$ Two years later, however, Representative Zimmer offered the most definitive statement on the matter. On one occasion, he opined that had the Kankas known their nearby neighbor was a sexoffender, "[ $\mathrm{t}]$ hey believe, and I believe, that little Megan would be alive today." 162 On another occasion, Representative Zimmer simply asserted as a matter of fact that "had [the Kankas] known that an offender lived directly across the street from them

157. Legislators in Congress, at least, might have discussed a 1995 study by the Washington State Institute for Public Policy. This report indicated that the state's community-notification law helped the police track sexual offenders but did not significantly reduce recidivismwithin this group. Eric Houston, Law Is Helping Police Track Sex Offenders, SEATTLE Post-INTELLIGENCER, Oct. 5, 1995, at B2, LEXIS, News Library, SEAPIN File.

158. E.g., 140 CONG. REC. 24,005 (1994) (statement of Sen. Lautenberg) (arguing that if there had been community notification, “just perhaps, just perhaps, Megan Kanka would be alive today").

159. Id. at 22,786 (statement of Sen. Biden).

160. E.g., id. at 21,448 (statement of Sen. Dole) ("[I]f [the Kanka family] had known about the criminalhistory of Megan's killer, there's a good chance that Megan would still have a childhood and a future.").

161. Id. at 22,699 (statement of Sen. Gorton).

162. 142 CONG. REC. 10,311 (1996) (statement of Rep. Zimmer). 
... Megan would be alive today." 163

Some federallegislators moved beyond the Megan Kanka narrative to establish the effectiveness of the bill. These representatives argued that Megan's Law would empower parents and communities to protect themselves by giving them valuable information. ${ }^{164}$ In addition, some claimed that Megan's Law would improve the effectiveness of the police by providing them with an investigatory database ${ }^{165}$ and by allowing them to offer more complete background checks on applicants for childcare jobs and scoutmaster positions. ${ }^{166}$

New York legislators also argued that Megan's Law would enhance child safety within the state. Like their federal counterparts, a few New Yorkers suggested that Megan's Law would have saved the lives of already dead victims. Senator Skelos, for instance, quoted Maureen Kanka's assertion that, had the law been in place in New Jersey, Megan would still be alive. ${ }^{167}$ Assemblyman Warner claimed that the four-yearold victim in his area would have been saved by Megan's Law. ${ }^{168}$ These examples were the exception, however. In the main, New York proponents of Megan's Law articulated a reasoned basis to believe that Megan's Law would protect children. Supporters argued, among other things, that it would make offenders afraid to reoffend because of an increased risk of detection, ${ }^{169}$ enhance police detection of sex offenders, ${ }^{170}$ and empower parents and neighborhoods to protect children because "[p]olice can't be everywhere." 171

The New York debate included a specific challenge to this assertion that the world would be safer with Megan's Law. Assemblywoman Glick stated:

I really, in my heart of hearts, believe that we are providing a false sense of security to parents, grandparents, maybe aunts and uncles about how they can do something, they can call a number, they can get some information, and if they can somehow paint a big letter on a particular house, that will prevent somebody from harming some kid. ${ }^{172}$

163. 142 CONG. REC. H11,133 (daily ed. Sept. 25, 1996) (statement of Rep. Zimmer). 164. 142 CONG. REC. 10,313 (1996) (statement of Rep. Jackson-Lee) (suggesting that school officials, community groups, and others will benefit from dissemination of information).

165. 142 CONG. REC. H11,134 (daily ed. Sept. 25, 1996) (statement of Rep. JacksonLee).

166. 139 CONG. REC. 31,252 (1993) (statement of Rep. Fish) (regarding child care jobs); 142 CONG. REC. 7747 (1996) (statement of Sen. Gramm) (regarding scoutmaster positions).

167. N.Y. Senate, supra note 105, at 6571 (statement of Sen. Skelos).

168. N.Y. Assembly, supra note 43, at 394 (statement of Mr. Warner).

169. See id. at 363 (statement of Mr. Polonetsky).

170. See id. at 300 (statement of Mr. Feldman).

171. Id. at 370 (statement of Mr. Robach).

172. Id. at 358 (statement of Ms. Glick). 
Legislators in both Congress and the New York legislature suggested a more ethereal benefit to Megan's Law: it would give meaning to Megan Kanka's life. This claim was premised on the idea that the new legislation was Megan's "legacy ... her gift to all children whose lives will be saved." ${ }^{173}$ Adoption of the bill would mean that Megan's life "will not have been in vain." ${ }^{174}$ New York Senator Leibell suggested that "[1]ittle Megan, with her short life has led my colleagues and I here today to deliberate this bill," ${ }^{175}$ and his colleague, Senator Libous, put it most dramatically: "Ladies and gentlemen, a simple vote of yes today from the Senate[,] and a vote from the Assembly[,] and a quick stroke of the pen from Governor Pataki will . . . provide a lasting legacy to a child whose only flaw was her wide-eyed innocence." 176

\section{Discussion of the Law's Problems}

Representative Watt of North Carolina proffered the only serious legislative critique of the federal Megan's Law. ${ }^{177}$ His criticisms of the legislation were not particularly scathing; his restraint may have been, in part, because he recognized that any public opposition to the bill could be very unpopular and a real political liability. $\mathrm{He}$ explained, "I know that tomorrow when I get the messages off my machine in the office, there will be a line of messages from people saying . . . that I have just lost my mind on this bill. That always happens." ${ }^{178}$ Watt's comments were somewhat vague; he spoke on two occasions and briefly mentioned several concerns about Megan's Law. On May 7, 1996, he argued that the two problems with the law were that it presumed people guilty of a crime after they had served their sentence for that offense, and that it constituted an unjustified incursion into the states' rights to decide whether they wanted community notification. ${ }^{179}$ On September 25, 1996, he proffered three concerns. First, he contended that the bill should have been put through the Committee on the Judiciary (although he conceded it would have been voted out of committee); second, he stated that it improperly punished a person for a crime afterhe had paid his debt to society; and third, he argued that it created a presumption of guilt, in that every person ever convicted of a sexual offense was now presumed guilty of new offenses. ${ }^{180} \mathrm{He}$ asserted that the bill's violation of these last two principles was

173. 142 CONG. REC. 10,311 (1996) (statement of Rep. Zimmer).

174. Id. at 10,361 (statement of Rep. Fox); see also id. at 8600 (statement of Rep. Jackson-Lee) ("We owe it to Jennifer, Elizabeth, Monique and Megan and all of the others whose lives have been snuffed out as a result of violent crimes.").

175. N.Y. Senate, supra note 105, at 6644 (statement of Sen. Leibell).

176. Id. at 6647 (statement of Sen. Libous).

177. Representative Watt only spoke out against the 1996 Megan's Law provisions.

178. 142 CONG. REC. H11,133 (daily ed. Sept. 25, 1996) (statement of Rep. Watt). Indeed, some media commentators have vilified those who questioned Megan's Law. The New York Daily News, for instance, referred to Judge Denny Chin, who struck down New York's Megan's Law, as “the pervert's pal.” Rogue's Gallery of Junk Judges, N.Y. DAILY NEWS, Mar. 31, 1996, at 40.

179. 142 CONG. REC. 10,315 (1996) (statement of Rep. Watt).

180. 142 CONG. REC. H11,133 (daily ed. Sept. 25, 1996) (statement of Rep. Watt). 
"simply un-American." 181

With respect to Representative Watt's claim that the bill violated the basic presumption of innocence, Representative McCollum-in a rare instance of one federal legislator directly responding to a colleague's comment—argued that Watt was

being a little bit too creative with regard to the presumption of innocence comments he made. Remember that the person who is registering here . . . is somebody who has been convicted of a sexual offense ... and this is really part of what the consequences are that go with being convicted of the acts that are delineated in the bill. ${ }^{182}$

The broader concern that this legislation imposed unjustified burdens on sex offenders was addressed principally by discussing the need to balance the rights of convicted offenders against those of children. Some legislators couched this balance in legalistic terms, citing court precedent purportedly establishing as a matter of law, that the "rights of potential victims supersede the rights of predators." ${ }^{183}$ Some noted that convictions were public knowledge, and that the bill balanced the rights of all concerned by simply distributing otherwise public information to those who needed it. ${ }^{184}$ Others, using their floor speech as an opportunity to preach, were more lyrical:

I think it is important that we stand on the side of civil liberties. But when I think of an innocent child, one who cannot defend herself or himself, one who cannot speak for themselves, one who may be torn away from the parent, torn away from the custodian, torn away from the guardian, who is now with someone who preys upon them, then my voice raises for that innocent child against that violent sexoffender, against that child abuser, against that murderer. In fact, my voice rises for all the innocent children in this country..$^{185}$

Legislators addressed Watt's federalismconcerns as well. Representative McCollum contended that the 1996 bill was not a mandate, but rather an encouragement. ${ }^{186}$ Senator Biden argued that states were still permitted flexibility under the law, but noted the importance of a nationwide system of registration. ${ }^{187}$

181. Id.

182. Id. (statement of Rep. McCollum). Representative Lofgren, who followed Representative McCollum, concurred with McCollum, stating that "the presumption of innocence ends when the conviction is obtained." Id. at H11,134 (statement of Rep. Lofgren). Lofgren, showing solidarity with her Democratic colleague Watt, did concede that "it cannot be a popular position to stand up and speak what you think the Constitution calls out for. ... [T] he gentleman from North Carolina [Mr. Watt], although I do not agree with him on this issue, has certainly shown integrity in standing up for what he believes the Constitution requires." Id. (alteration in original).

183. 142 CONG. REC. 10,311 (1996) (statement of Rep. Zimmer).

184. Id. at 10,314 (statement of Rep. Lofgren).

185. 142 CONG. REC. H11,134 (daily ed. Sept. 25, 1996) (statement of Rep. JacksonLee).

186. 142 CONG. REC. 10,315 (1996) (statement of Rep. McCollum).

187. See id. at 7748 (statement of Sen. Biden). Biden's argument about the need for a nationwide system of registration was a rare occasion in which congressional 
Members of Congress did make passing reference to one common critique of Megan's Law: the risk of vigilante retaliation against offenders. Although Representative Watt did not raise this issue in his comments, Representative Lofgren sought to allay any concerns. Pointing to the successful example of California's notification law, she argued that vigilantism was not a necessary result of the legislation. ${ }^{188}$ Representative Cunningham, on the other hand, seemed more sanguine, asserting that "perhaps a sexual predator's life should be just a little more toxic than someone else in the American citizenry." 189

Unlike Congress, the New York legislature spent a significant amount of time discussing possible problems with Megan's Law. Critics of the bill offered a more nuanced attack on the legislation than Representative Watt's generalized claims. For instance, Senator Patterson argued that because most child sexual assault occurs within the home, and goes unreported, Megan's Law would have minimal net benefit. ${ }^{190}$ This claim seemed to encompass two criticisms. First, most sexual offenders would never be subject to registration and notification because they would not be caught. Second, many sexual abuse victims would not receive any new benefit from registration and notification, because they were victimized at the hands of relatives, rather than strangers.

Legislators were also dubious of the law's fundamental assumption that mere notice would be enough to keep children from danger. One assemblywoman noted that children often disobey parental restrictions, and feared that placing a house off limits might create an enticement for children. ${ }^{191}$ Others worried that the existence of the legislation would actually endanger children by creating an unjustified illusion of security. ${ }^{192}$ Another legislator conceded that registration would reduce crime by helping police solve crimes; he argued, however, that registration alone-without notification-would do that job nicely. ${ }^{193}$

Questions about the constitutionality of the provision were discussed at length within both the Assembly and Senate. Legislators debated whether the retroactivity

rhetoric was used in ways that might specifically assist a court reviewing the federal Megan's Law. Although it is unlikely that the courts would question the power of Congress to create standardized data collection given the Supreme Court's reading of the Constitution's spending power in South Dakota v. Dole, 483 U.S. 203 (1987), W. Paul Koenig's discussion of the need for a national databas e might provide sufficient basis to uphold the law even under the Commerce Clause. W. Paul Koenig, Does Congress Abuse Its Spending Clause Power by Attaching Conditions on the Receipt ofFederal Law Enforcement Funds to a State's Compliance with 'Megan's Law”?, 88 J. CRIM. L. \& CRIMINOLOGY 721 (1998).

188. See 142 CONG. REC. 10,314 (1996) (statement of Rep. Lofgren).

189. Id. Representative Cunningham was not explicitly endorsing vigilantism, and the phrase could be seen simply to suggest that community opprobrium was an acceptable punishment for sex offenders. Nonetheless, his rhetoric does suggest, at minimum, a lack of concern about this bill's impact on the life of a sex offender. At most, it is open tolerance for vigilantism.

190. See N.Y. Senate, supra note 105, at 6572 (statement of Sen. Patterson).

191. N.Y. Assembly, supra note 43, at 311 (statement of Ms. John).

192. Id. at 397 (statement of Mr. Sullivan); id. at 358 (statement of Ms. Glick).

193. See N.Y. Senate, supra note 105, at 6621 (statement of Sen. Leichter). 
of the bill would implicate Ex PostFacto Clauseconcerns, ${ }^{194}$ and supporters of the bill responded by noting the inclusion of a severability clause. ${ }^{195}$ In one speech, Senator Marchi sought to clarify that the bill was gender neutral; "knowing . . . the quixotic nature of judicial interpretation[]," he wanted to prevent any future legal attacks on the legislation. ${ }^{196}$ Not surprisingly, issues of federalismdid not arise explicitly in New York. They did surface implicitly, however. First, on several occasions legislators suggested that New York was required, by federal law, to adopt a community-notification provision. ${ }^{197}$ These comments made no reference to the fact that the federal Megan's Law was not an actual mandate, but rather a condition of receiving a full dose of federal crime-fighting funds. Second, New York legislators argued that, in order to maintain the state's traditional leadership position in the creation of new law, the legislature had to move quickly. ${ }^{198}$ They claimed that other states were moving swiftly to adopt Megan's Law and that the state was at risk of losing its cutting-edge reputation. ${ }^{199}$

One of the most potent criticisms of the bill, utterly absent in the federal debate, involved the application of Megan's Law to cities and high-density neighborhoods. A representative from New York City, Assemblyman Sullivan, argued that the bill would provide little protection for children in cities because: "All any pervert has to do who lives on my street is hop on the subway and in five minutes he is in another community where there are children who are going to the store for milk or going to school." ${ }^{200}$ Sullivan's argument was taken one step further by a grudging supporter of the bill, Assemblyman Towns, who suggested that Megan's Law might actually make some areas more dangerous. He noted that neighborhood pressure, in suburbs and smaller towns, to exclude convicted sex offenders could result in "warehousing of these people in certain communities" ${ }^{201}$ —namely, high-density cities, where these individuals would be less noticeable.

In another distinction between the federal and state debates, legislators in New York expressed worry for those offenders subject to registration and community notification. Legislators repeatedly brought up concerns about vigilantism, for instance. $^{202}$ They were troubled that individuals might be subject to violence from angry community members. ${ }^{203}$ Some were concerned with the stigma engendered by notification as well as the dangers of erroneous notification. ${ }^{204}$ Others argued that the provision would create a barrier for effective treatment of sex offenders because they

194. See, e.g., N.Y. Assembly, supra note 43, at 309-10 (statement of Ms. John) (questioning bill's constitutionality); $i d$. at 384-86 (statement of Mr. Feldman) (asserting bill was constitutional).

195. N.Y. Senate, supra note 105, at 6612 (statement of Sen. Skelos).

196. See id. at 6605-08 (statement of Sen. Marchi).

197. See, e.g., id. at 6588 (statement of Sen. Nozzolino).

198. $I d$.

199. See id.

200. N.Y. Assembly, supra note 43, at 397 (statement of Mr. Sullivan).

201. Id. at 407-08 (statement of Mr. Towns).

202. See, e.g., id. at 297 (statement of Mr. Sullivan); N.Y. Senate, supra note 105, at 6618 (statement of Sen. Leichter).

203. N.Y. Assembly, supra note 43, at 357 (statement of Ms. Glick).

204. N.Y. Senate, supra note 105, at 6618 (statement of Sen. Leichter). 
would be unable to integrate into society. ${ }^{205}$ Couldn't parole provide equally effective community protection, one legislator wondered. ${ }^{206}$

The bill's backers, for the most part, sidestepped these concerns. They did address the most salient issue, vigilantism. The principle response to this critique of Megan's Law was a call for law and order: vigilantism would not be tolerated. ${ }^{207}$ In any case, they anticipated that such incidents would be rare. ${ }^{208}$ Despite the se more levelheaded comments, at least one representative articulated the bubbling undercurrent of the debate, asserting that even if individuals were "wrongly abused in their neighborhoods ... I don't care." ${ }^{209}$ Proponents also dismissed the suggestion that parole would be an adequate substitute; supporters instead suggested that Megan's Law would provide additional support to an overwhelmed parole office..$^{210}$

\section{A CRITICAL A NALYSIS OF LEGISLATIVE RHETORIC}

Despite the one-sided support for Megan's Law, legislators engaged in an extensive debate about the law's provisions. This Part critically reviews the rhetoric used in the Megan's Law legislative debates. First, it considers the consequences of using childvictim narratives as a form of public-policy argument. Next it discusses the use of statisticalmanipulation in making the case for the law. It then shows that the debates were framed almostentirely in terms of child protection. Finally, it explores implicit and explicit claims proffered about the demographic impact of Megan's Law.

\section{A. Stories as Public-Policy Claims}

Both federal and New York legislators exhibited a preference for advocacy through storytelling. In the federal debate, virtually all of these stories were child-victim narratives. Legislators used the story of Megan Kanka's rape and murder, for example, to show both that convicted sex offenders do terrible things to children and that the bill would protect children like Megan. These stories were told in vivid, graphic form, including minute details like "bearded" men, "specialty" condoms purchased at "Seductions," and a girl abducted from "her pink bike into a black truck." ${ }^{211}$ Embedded in these stories were not only tales of childhood innocence but lush images of dark criminality. It was easy to picture these horrible crimes and, in doing so, to feel uneasy.

While New York legislators relied less on narrative, they also marbled their comments with stories. Their child victim stories were somewhat less vivid, however, and lacked the drama of stories told in Congress. On the other hand, legislators in New York told more varied stories in the course of their remarks.

Despite the differences in the storytelling approach, the two debates exhibited a similar infatuation with storytelling as rhetorical trope. Why were stories such an

205. N.Y. Assembly, supra note 43, at 359 (statement of Ms. Glick).

206. See id. at 371-80 (various statements of Mr. Grannis).

207. See N.Y. Senate, supra note 105, at 6619 (statement of Sen. Skelos).

208. N.Y. Assembly, supra note 43, at 301 (statement of Mr. Feldman).

209. Id. at 390 (statement of Ms. Wirth).

210. See, e.g., id. at 384 (statement of Mr. Feldman).

211. Supra text accompanying notes 100-02. 
important tool for legislators? First, narratives are powerful. Humans make sen se of the world through stories and metaphors. ${ }^{212}$ They are also a particularly easy way to convey an idea, ${ }^{213}$ and a uniquely effective method of capturing a listener's attention. ${ }^{214}$ They also make a more powerful emotional appeal than logical claims ${ }^{215}$ because they encourage the listener to humanize a problem. Graphic, detailed narratives are particularly effective; due to human-cognitive-processing limitations, vivid stories are easier to recall, and harder to refute, than statistical or logical claims. ${ }^{216}$

Legal rhetoric is thick with narrative. Judicialopinions begin with a statement of the facts. This story, posing as an objective recitation of truth, is carefully drawn to lead to the court's conclusions. ${ }^{217}$ A judicial opinion is typically designed to appear inevitable given the facts. ${ }^{218}$ Judicial storytelling helps establish that a party is "an innocent victim or an undeserving malefactor." ${ }^{219}$ Martha Nussbaum contends that detailed judicial storytelling can evoke a sense of the moral issue at play in a case. Discussing Hudson v. Palmer, ${ }^{220}$ a prisoner suit challenging the propriety of a cell search, Nussbaum argues:

If we can imagine the items seized in the shakedown search-a photograph, a letter-we can imagine not only the fact that Palmer possessed these items legitimately, but also the character of the interest he was likely to have in these fragile signs of his humanity. We are likely, then, to appreciate more vividly the malicious character of the intrusion of the guard, whose destruction of a photograph served no conceivable institutional goal other than intimidation and humiliation. ${ }^{221}$

212. Susan Bandes, Empathy, Narrative, and Victim Impact Statements, 63 U. CHI. L. REV. 361, 383 (1996) ("We make sense of the world by ordering it into metaphors, and ultimately into narratives with familiar structures and conventions-plot, beginning and end, major and minor characters, heroes and villains, motives, a moral.").

213. Marc A. Fajer, Authority, Credibility, and Pre-understanding: A Defense of Outsider Narratives in Legal Scholarship, 82 GEO. L.J. 1845, 1857 (1994) ("Narrative can create empathy that helps listeners to understand concepts that might be difficult for them to grasp when conveyed as abstractions.").

214. See, e.g., Abrams, supra note 39, at 1006-07 (describing one law scholar's narrative as "pungen[t]" and "jarring").

215. See Delgado, supra note 35, at 2440; Gerald P. López, Lay Lawyering, 32 UCLA L. REV. 1, 10 (1984).

216. See Richard E. Nisbett \& LeE Ross, Human InFEREnCE: StRATEgies And SHORTCOMINGS OF SOCIAL JudGMENT 45-61, 123-25 (1980). Timur Kuran and Cass Sunstein pay particularattention to this "availability heuristic," by which individuals estimate the probability of an event based on how easily it is recalled. Because people can recallvivid stories particularly easily, Kuran and Sunstein contend that arguments grounded in such story-based claims are unusually effective at swaying citizens. See Kuran \& Sunstein, supra note 32 , at 706.

217. See Wald, supra note 30 , at $1386-89$ (arguing that a judge "consciously relates a 'story' that will convince the reader [the case] has come out right").

218. See id. at 1386, 1389.

219. Id. at 1386.

220. 468 U.S. 517 (1984).

221. Nussbaum, supra note 30 , at 1501 . 
Judicial opinions are "not just 'storytelling' exercises seeking to create dramatic tension"; 222 "[e]very judge knows the facts should carry an opinion.", 223

Likewise, trials are packaged as stories. Trial lawyers create opposing master narratives, theories of the case, into which they plug the evidence adduced at trial. ${ }^{224}$ One commentator explained that " $[\mathrm{t}]$ he American adversary criminal trial is a regulated storytelling contest between champions of competing, interpretive stories." ${ }^{225}$ Lawyers use narratives for good reason: they effectively engage and convince jurors. As Justice Souternoted in a recent dissent, "research redoundingly proves that the story format is a powerful key to juror decision making." 226

Legislators tell stories for a variety of reasons. For instance, storytelling can be a good political strategy for legislators seeking media attention. Legislators who want their statements to be covered in the press, and particularly on television, must compete with many other news producers. ${ }^{227}$ They need to use rhetoric that appeals to the media and society at large. The public loves crime narratives; Americans seem to have a limitless capacity for police dramas, true crime accounts, and gory news coverage. ${ }^{228}$ The media, in turn, love these stories because they draw viewers and readers. The press prioritizes dramatic stories ${ }^{229}$ and makes a concerted effort to cover particularly terrible crimes. ${ }^{230}$ The media also have a stake in perpetuating coverage of these crimes; the Jon Benet Ramsey and O.J. Simpson cases both exemplify the media's successful efforts to continuously remarket a crime story.

When legislators recount gruesome crime narratives, they assist the media in reactivating old, popular crime stories. The public has already proven a long-term interest in the Megan Kanka case, for instance. ${ }^{231}$ When legislators speak out for Megan's Law by retelling horrible narratives, they make themselves characters in the underlying crime stories. Their speech sends the message, both explicitly and implicitly, that their efforts are directly related to the originalcrimes. For the media and public, then, the legislative debate is merely the newest twist in an old, compelling crime saga, a perfect excuse to revisit the riveting, horrific murder that began it all.

222. Patricia M. Wald, A Reply to Judge Posner, 62 U. CHI. L. REV. 1451, 1453 (1995).

223. Wald, supra note 30, at 1389.

224. See Richard K. SHerwin, W hen Law Goes Pop: The VANiShing Line Between LAW AND Popular Culture 41 (2000); Michael E. Tigar, EXAMining W ITNESSES 5 (1993).

225. Gary Goodpaster, On the Theory of American Adversary Criminal Trial, $78 \mathrm{~J}$. CRIM. L. \& CRIMINOLOGY 118, 120 (1987).

226. Strickler v. Greene, 527 U.S. 263, 307 (1999) (Souter, J., dissenting) (quoting Elizabeth F. Loftus \& JAmes M. Doyle, Eyewitness Testimony: Civil AND CRIMINAL 5 (3d ed. 1997)).

227. See BEST, supra note 58, at 88.

228. See Gary W. Potter \& Victor E. Kappeler, Introduction to ConstruCTING CRIME: PERSPECTIVES ON M AKING NeWS AND SOCIAL PROBleMs 2-3 (Gary W. Potter \& Victor E. Kappeler eds., 1998).

229. See BEST, supra note 58, at 88.

230. Potter \& Kappeler, supra note 228, at 4.

231. A search of the LEXIS, News Library, ALLNWS File on November 5, 2000, seeking all documents since July 29, 1997, that included "Megan Kanka" produced over 1000 stories. 
There are other reasons, beyond political strategy, that explain the centrality of storytelling in the Megan's Law debate. For one thing, this type of rhetoric may have served as legally permissible retribution against sexoffenders. Legislators have a very limited ability to punish individuals who have already broken the law. The Constitution's Ex PostFacto Clause ${ }^{232}$ prohibits a legislature fromincreasing a penalty on an offender after he has committed a crime. ${ }^{233}$ Similarly, the constitutional prohibition on bills of attainder ${ }^{234}$ forbids "legislative acts, no matter what their form, that apply either to named individuals or to easily ascertainable members of a group in such a way as to inflict punishment on them without a judicial trial." 235

By interlinking the new laws with child-victim narratives, however, legislators may have sought a legal means to achieve the social benefits of retribution. Megan's Law delivers a severe blow to the entire community of convicted sexoffenders. While most courts agree that community notification is not punishment in a constitutional sense, ${ }^{236}$ it is punishment in any common-sense understanding of the word ${ }^{237}$ It makes an offender's life more unpleasant. Not only is an offender stripped of anonymity, he is subject to public censure, and potentially personal violence. One can easily imagine that the public felt a sense of retributive satisfaction when legislators recounted cases of victimization and asserted that Megan's Law was enacted in direct response to these stories. Indeed, given the delays in criminal trials-it took almost three years for Jesse Timmendequas to be convicted of Megan's murder ${ }^{238}$ — this legislative retribution was far swifter than any offered by the courts.

Another reason why legislators may retell victim stories is that by linking a law to an individual incident, society may be better able to make sense of the incident. Legislative rhetoric thus creates coherence out of random evil acts. Legislators

232. U.S. CONST. art. I, $\S 10$, cl. 1.

233. Calder v. Bull, 3 U.S. (3 Dall.) 386, 390 (1798) (holding that the Ex Post Facto Clause prohibits enactment of law that "aggravates a crime" or "changes the punishment, and inflicts a greater punishment").

234. U.S. CONST. art. I, $\$ 10$, cl. 1.

235. United States v. Lovett, 328 U.S. 303, 315 (1946).

236. E.g., Roe v. Office of Adult Prob., 125 F.3d 47 (2d Cir. 1997); Doe v. Poritz, 662 A.2d 367 (N.J. 1995). A minority of courts have held that it is punishment.E.g., Kansas v. Myers, 923 P.2d 1024, 1043 (Kan. 1996). Courts have also held that Megan's Law is not an unconstitutional bill of attainder. See, e.g., Roe v. Farwell, 999 F. Supp. 174, 192 (D. Mass. 1998). For an extensive list of court decisions evaluating the constitutionality of state Megan's Laws, see Carol Schultz Vento, Annotation, Validity, Construction, and Application of State Statutes Authorizing Community Notification of Release of Convicted Sex Offender, 78 A.L.R.5TH 489 (2000).

237. Symposium, supra note 20, at 65-66 (1997) (comments of Hon. John J. Gibbons, former Third Circuit judge) (arguing that notification is punishment because it "will affect a person's ability to find a job, meet a companion and establish a stable relationship, and initiate membership in a church"); Telpner, supra note 25, at 2055 (arguing that Megan's Law is punishment under a "broad, common-sense meaning of the term").

238. Timmendequas was convicted on May 30, 1997. William Glaberson, Man at Heart of Megan's Law Convicted of Her Grisly Murder, N.Y. TIMES, May 31, 1997, at A1. He was sentenced to death on June 20, 1997. William Glaberson, Killer in 'Megan' Case Sentenced to Death, N.Y. TIMES, June 21, 1997, at A1. 
repeatedly asserted that the law insured that these individual victims had not died in vain. Thus, the rhetoric of Megan's Law transforms Megan's death into a gift and the bill becomes that narrative's final chapter. The story now ends on a vaguely upbeat note: one child's death assures the safety of all other children. Like retribution, this process allows society to accept, and move on from, a horrible violation.

Finally, storytelling may give voice to an outsidergroup: children. Children cannot vote and rarely speak before legislatures. Perhaps as a consequence, they are especially plagued by social problems. They suffer disproportionately frompoverty. ${ }^{239}$ And while overall crime rates have been dropping in recent years, violence against children has not abated. ${ }^{240}$ Children, therefore, could be seen as an "outsider" group, at least with respect to public policy. Commentators have suggested that one significant benefit to storytelling is its capacity to give voice to outsider groups. ${ }^{241}$ Of course, not all stories empower outsiders. "The dominant group creates its own stories, as well." ${ }^{242}$ A child-victim story, particularly when told by a popularly elected legislator, could be viewed not as an outsider narrative, but rather as the majority's narrative, reflecting a majoritarian effort to impose greater burdens upon an offending minority. ${ }^{243}$ Nonetheless, it is at least arguable that the use of narratives in the Megan's Law legislative debate may have functioned as a uniquely powerful way to convey the experience of children.

The use of stories in legislative debate is not unproblematic, however. First, storytelling is an argumentative method that deals with the single case. It is sometimes difficult to strain a single, definitive meaning from a story. For instance, Megan's murder could be read as the story of a parent who lacked critical information about neighborhood safety; the tale of a bad parent who did not properly supervise her seven-year-old daughter; or the account of a media that oversexualized children. Depending how one interprets Megan's story, then, it may prove the need for community notification, state supervision and training of all parents, or censorship of the media. Unlike logical claims, which are putatively designed to convey a single

239. Almost twice as many children are in poverty, as a percentage matter, as the nation's population as a whole.See America's Unfinished Agenda: The Poor Are Still There, and Need Helping, ECONOMIST, May 20, 2000, at 24.

240. Gayla Margolin \& Elana B. Gordis, The Effects of Family and Community Violence on Children, 51 ANN. REV. PSYCH. 445, 446 (2000).

241. Jerome McCristal Culp, Jr., Telling a Black Legal Story: Privilege, Authenticity, "Blunders, " and Transformation in Outsider Narratives, 82 VA. L. REV. 69, 88 (1996) ("Stories can alter public debate by attacking and questioning the underlying stories that we tell about public policy and the law. Stories can alter public policy by adding aspects to the stories currently being told, or by introducing questions that are not being discussed.").

242. Delgado, supra note 35 , at 2412 .

243. Cf. Bandes, supra note 212, at 410-11 (suggesting that both rapist and rape victim are "outsiders"). One could even make the argument that use of the child's story is a form of theft, the appropriation of a few families' pain in the aid of a tough crime ideology. Cf. Trina Grillo \& Stephanie M. Wildman, Obscuring the Importance of Race: The Implication of Making Comparisons Between Racism and Sexism (or Other-Isms), 1991 DUKE L.J. 397,405-10(discussing how some African-Americans may hear whites discussing the power of racism and feel that this is an appropriation of pain). 
meaning, the interpretation of a story may depend more on a listener's preconceptions than the content of the narrative itself.

Another difficulty with storytelling as legislative argument is that it has the potential to stifle debate; it is very difficult to disagree with an emotional and horrifying story. ${ }^{244}$ What was the proper response to a legislator who explained that she supported the bill because Megan was killed? Legislators could not have argued that Megan was not killed. They could have claimed that Megan's Law would not have prevented Megan's murder, but this argument required a direct challenge to the victim's parents, who asserted that community notification would have saved Megan's life. They could have tried to ignore the proponent's story, or, like New York SenatorLeichter, argue that the recitation of a story was a mere appeal to emotion. ${ }^{245}$ Legislators opposing the bill were left few attractive options.

Ironically, the "true" story of Megan Kanka is open to factual dispute. At the core of supporters' claims for Megan's Law was the assumption that Richard and Maureen Kanka were in fact unaware that a sexoffenderlived nearby. Yet this assumption may not be true. Several of the Kankas' neighbors stated that they knew a sex offender-albeit, not Timmendequas himself-lived in the house where Megan was killed. ${ }^{246}$ Moreover, they asserted that Maureen Kanka admitted she knew that this individual lived there. ${ }^{247}$ The Kankas fervently denied this claim. ${ }^{248}$ One neighbor was very critical of what he saw as an intentional campaign of denial within the neighborhood:

When I read that in the papers [that neighbors had no knowledge that three sex offenders were living on the block], I was pissed. They all knew what Joey Cifelli did. It was common knowledge. How could those neighbors go to bed at night and sleep and say that they didn't know that he was a pervert? ${ }^{249}$

If the Kankas did know that a sex offender lived next door, and if the bill's supporters were accurate in claiming that notification would allow good parents to protect their children, the resulting implication would have been that the Kankas were partially culpable for Megan's death. In addition, it would have made the Kankas' advocacy for Megan's Law look downright deceitful. Whether or not the Kankas knew their neighbor was a sex offender, the remarkable thing is that not a single legislator was

244. In a similar vein, Farber and Sherry argue that it is difficult to disagree with personal stories because "it's hard to say anything critical about the story without implicating the storyteller." FARBER \& SHERRY, supra note 39, at 89.

245. See note 105.

246. Tim O'Brien, Would Megan's Law Have Saved Megan?, 145 N.J. L.J. 109 (1996). The person who lived in the home, Joey Cifelli, had been previously convicted of carnal abuse, sodomy, and impairing the morals of a nine-year-old girl. Id.

247. Id.

248. Donna Murphy Weston, Megan's Law Based on Fallacy: Did Parents Know About a Molester? , RECORD (Bergen County, N.J.), July 9, 1996, at A1, LEXIS, News Library, NJREC File. Richard Kanka responded that the New Jersey Law Journal wanted to "undermine what me [sic] and Maureen have been doing all these years." Id.

249. O'Brien, supra note 246, at 109. 
willing to question the Kankas' account. No doubt, a proponent of the bill would have taken great offense at such a challenge. Yet legislators' failure to confront these underlying assumptions show the difficulty in challenging arguments framed as stories. To attack the basic terms of the Megan Kanka narrative was a political impossibility. ${ }^{250}$

Even accepting that the use of narrative has value, however, legislators were very selective in their storytelling choices. Legislators in both Congress and New York ignored the stories of victimizers. To be sure, they mentioned offenders in the context of their crimes. They did not, however, attempt to explain how these offenders became abusers. A few legislators observed that many offenders were themselves sex-abuse victims, ${ }^{251}$ but they framed these observations in terms of individual narratives. Similarly, legislators did not present accounts of offenders battling with rehabilitation or an irresistible compulsion to molest, or stories of offenders victimized by local vigilantes. ${ }^{252}$ Only Megan's Laws' supporters appropriated the power of narratives; in a debate centered on stories of victims, opponents' logic-based arguments lacked rhetorical vibrancy.

The use of stories in legislative debate is neither purely good nor purely bad. The decision to recount victim stories may yield positive social, as well as political, benefits. On the other hand, they must be used carefully, because they have the potential to stifle dialogue. What is particularly troubling about storytelling in the Megan's Law debate was that the stories presented a one-sided picture of the world-a picture that had already gained public acceptance prior to the debate. While the use of child narratives proved that legislators watched the same gory news coverage as everyone else, it did little to educate the public to the varied, and complicated, causes of these incidents.

\section{B. Uncritical Statistical Claims}

250. The Megan Kanka narrative was a particularly powerful and troubling story. It is certainly possible that some narratives-those involving less emotionally charged themes, or those that did not benefit from extensive media attention-could be effectively refuted within a political debate. In the case of Megan Kanka, for instance, the counternarrative of the Kankas' neighbors might have had greater impact had it surfaced in the first weeks after the incident.

251. See, e.g., 142 CONG. REC. 10,314 (1996) (statement of Rep. Lofgren).

252. Even at the time of these debates, legislators could have found cases of offenders victimized as the result of community-notification laws. A 1993 study of Washington's notification law showed that twenty-six percent of sex offenders covered by the law suffered harassment. Katherine Seligman, Sex Offender Branding: Bad, Good, or Ugly? Public Notification Alerts Public, Hounds Ex-Cons, PHOENIX GAZETTE, Mar. 9, 1994, at A1, LEXIS, News Library, PHNXGZ File. One early example of vigilante activity involved the well publicized case of Joseph Gallardo, whose family's home was burned by angry neighbors. Karen Alexander et al., Child Rapist Says He'll Return to Home Despite Arson, SeAtTle Times, July 13, 1993, at A1, LEXIS, News Library, SEATTM File. Legislators also declined to tell stories of "collateral damage," cases where innocent victims were beaten because angry neighbors mistook them for convicted offenders. See, e.g., Barry Meier, 'Sexual Predators' Find Sentence May Last Past Jail, N.Y. TIMES, Feb. 27, 1995, at A1. 
Although secondary to narratives, arguments based on statistics played an important role in both the federal and New York Megan's Law debate. As with storytelling, the role of statistics varied between the two venues. In the federal debate, statistics were offered to prove both the severe extent of the sex-crime problem and the high recidivism rate for these offenders. Rarely did they shed much light on whether, or how, Megan's Law would address these concerns. ${ }^{253}$

Forinstance, legislators cited a variety of statistics relating to rates of victimization. Representative Jackson-Lee described the problem as high rates of child abuse and neglect ${ }^{254}$ while Representative Ramstad framed it as high rates of child abduction. ${ }^{255}$ Numbers have a way of dazzling the listener, and it is worth parsing these statistics slowly. For example, what sorts of incidents constitute the 50,000 cases of "abuse and neglect" cited by Jackson-Lee? ${ }^{256}$ According to the Children's Trust Fund of Texas, the source of this number, abuse and neglect are defined as

a person's action or failure to take action which has an adverse effect on a child's physical or mental health or welfare. Abuse includes physical, sexual, mental, or emotional harm. Neglect includes failure to provide a child with adequate care, food, clothing, shelter, or medical treatment, or placing a child in a potentially dangerous situation. ${ }^{257}$

The degree to which this broad classification exceeds the scope of Megan's Law is virtually self-evident. Megan's Law would do nothing to protect children from irresponsible parents, for instance.

Representative Ramstad cited a study indicating that, in 1988, 114,600 children were victims of attempted abduction, and 3200-4600 of actual abduction. ${ }^{258}$ The numbers appear to have come from a 1990 study commissioned by the U.S. Office of Juvenile Justice and Delinquency Prevention. ${ }^{259}$ While the senumbers seem daunting, the study

253. Identifying a statistical "reality" is an impossible task. Different studies, asking different questions, can produce different results. Also, it is difficult to evaluate the success of nonstandardized processes like rehabilitation of sex offenders, since these processes will vary based on the type of rehabilitation used, and the nature of the sex offenders' pathologies. Similarly, it is hard to quantify broad categories of crime like "abuse" or even "sexual abuse." As Joel Best establishes, there is no agreed-upon definition of "child sex abuse." BEST, supra note 58, at 83-85. While some believe it includes offenses like the seduction of a fourteen-year-old girl by a fourteen-year-old boy, others limit the categories to adults seducing children, or adults producing child pornography. $I d$. What is certain, however, is that statistics relating to abduction, pedophilia, and sexoffenses are both plentifuland contradictory. See, e.g., id.; R. Karl Hanson, The Science of Sex Offenders: Risk Assessment, Treatment and Prevention, 4 PSYCHOL. PUB. POL'Y \& L. 50 (1998).

254. See supra text accompanying note 122.

255. See supra text accompanying note 123.

256. See supra text accompanying note 122.

257. TeX. A\&M Univ. Pub. Policy ReSEARChInst., 1995 StATEWIDE CHILD SuRvey

EXECUTIVE SUMMARY, http://www.ctf.state.tx.us/html (last visited Feb. 9, 2001).

258. See supra text accompanying note 123.

259. DAVID FINKELHOR ET AL., MisSING, A BDUCTED, RUNAWAY, AND THROWNAWAY CHILDREN IN AMERICA: FIRST REPORT: NUMBERS AND CHARACTERISTICS NATIONAL INCIDENCE STUDIES 4, 10 (1990). 
carefully warns that the definition of "abduction" "is far broader than the stereotype many people have when they think of stranger kidnapping." ${ }^{260}$ It includes cases involving minimal coerced movement, exceedingly brief time of detention, and such "nonfamily" perpetrators as acquaintances and babysitters. ${ }^{261}$ The report contrasts abduction statistics with the number of "stereotypical kidnapping" cases, in which a child was taken a large distance, kept overnight, ransomed, or murdered. ${ }^{262}$ Using this "stereotypical kidnapping" statistic - the one the authors believed best represented the public's understanding of child abductions ${ }^{263}$ - there were 200 to 400 actual abductions in 1988. While this number may be unacceptably high, and a valid cause for concern, it is easy to see the rhetorical advantage of citing 114,000 cases rather than 400. Unfortunately, this larger number is deceptive. Legislators implicitly framed the crisis addressed by Megan's Law in terms of particular, gruesome cases; to the extent that legislators suggested that 114,000 such child murders were attempted each year, they misled their colleagues and the public.

Legislators also discussed high recidivism rates. Some legislators spoke of recidivism rates of sex offenders generally, ${ }^{264}$ while most focused principally on the reoffense rate of child sex offenders. ${ }^{265}$ While distinctions were sometimes made between generic "sex offenders" and "child sexoffenders," little or no distinction was offered between different sorts of sex offenses. It is unclear exactly what offenses these statistics refer to. For instance, within some jurisdictions, the promotion of prostitution is considered a sex offense. ${ }^{266}$ If these offenders have a high recidivism rate, that is more likely due to a passion for money than a fetish for child abuse. Legislators did not indicate whether open lewdness, indecent exposure, prostitution or other types of lower grade sex offenses-crimes that would not be covered by the federal Megan's Law-were included in their offense and recidivism rates.

In the federal debate, nobody questioned the statistics supporting Megan's Law. In part, this absence of criticism reflected an absence of critics within Congress. Given the onslaught of horrifying stories and the attending tone of moral indignation, a critique of supporters' statistical claims might have been treated akin to Holocaust denial. ${ }^{267}$ Nonetheless, given the nature of the statistics that were presented, listeners might have benefitted from closer scrutiny of supporters' claims.

To a lesser extent, this sort of loose play with statistics also surfaced in the New York debates. There, the only statistics mentioned seemed to relate to child sexual offenses.

260. Id. at 66 (emphasis omitted).

261. Id.

262. Id. at 67.

263. See id. at xii.

264. See text accompanying notes 125-27.

265. See text accompanying notes 128-32.

266. Alabama's Megan's Law, for instance, includes individuals convicted of promoting prostitution in the second degree. ALA. CODE $§ 13$ A-11-200 (1994). That prostitution provision, in turn, covers any individual who runs a prostitution operation with two or more employees. ALA. CoDE § 13A-12-112 (1994 \& Supp. 1999).

267. The parallel between the problem of child sexual assaults and the Holocaust was drawn implicitly in the New York Senate where one Senator invoked the phrase, oft used about the Holocaust, "We must never forget." N.Y. Senate, supra note 105, at 6588 (statement of Sen. Nozzolio). 
Gone were generic references to "victimization" and "abuse." Still, the statistics that were offered did not provide clear grounds for this particular law. For instance, Assemblyman Spano indicated that child sexualabuse rates were on the rise; ${ }^{268}$ he did not indicate whether there was a similar rise in adult sex abuse that received comparable treatment under Megan's Law. The statistics offered were underinclusive; they offered a basis for a law that regulated child sex offenders, but not the broader provisions of New York law that included offenders who victimized adults or who abused children in nonsexual ways.

Unlike the federallegislators, however, New York critics of Megan's Law challenged the use of statistics. For example, on several occasions legislators brought up the issue of family sex abuse. ${ }^{269}$ For some, the high rate of family sex abuse, and the low rate of conviction among these abusers, proved that Megan's Law would not affect most sex offenders. For others, this problem cut to the core of the Megan's Law premise: if mostsexabuse is occurring in the home, neighborhood notification would not address the problem. ${ }^{270}$ In either case, critics noted, the fact that most sex abuse cases occurred in the home undermined claims about the efficacy of Megan's Law.

Supporters of the bill heard these critiques. They conceded that Megan's Law might not be a panacea. This may explain, in part, why fewer New York legislators claimed that one or another specific child would have been saved by the bill. Nonetheless, supporters wanted the state to take some action. As one explained: "This bill isn't going to be the end all and this legislation isn't going to make my son 100 percent safe or any one else's son or daughter 100 percent safe, but it's a beginning, it's protection, and it's awareness, and it arms us." 271

In both venues, legislators used statistics to create the sense that a child sexualassault crisis was sweeping the nation and that Megan's Law would address this crisis. Yet the statistics, once read closely, often failed to establish the alleged seriousness of the problem. In addition, they documented problems well beyond the scope of the proposed legislation. Legislators made no effort to tailor their statistical evidence to the bill under consideration and, in the federal debates at least, these disingenuous claims went unchallenged.

\section{Child Protection as an Issue Frame}

In addition to sharing two particularly salient argumentative techniques - storytelling and statistics_both debates framed Megan's Law almost entirely in terms of child protection. This was expected given the name of the bill, but it did not accurately reflect the true scope of Megan's Law. Neither the federal nor the New York Megan's Law was limited only to offenders who victimize children. ${ }^{272}$ Legislators' decision to frame the debate in such limited terms must, therefore, be seen

268. See supra text accompanying note 135.

269. See supra text accompanying note 190.

270. See supra text accompanying note 190.

271. N.Y. Assembly, supra note 43, at 367-68 (statement of Ms. Destito). Similarly, Assemblywoman Clark noted that Megan's Law would not solve the larger problem of family sexual abuse and assault but nonetheless supported the bill. Id. at 398 (statement of Ms. Clark).

272. See supra text accompanying note 266. 
as a conscious rhetorical tactic. ${ }^{273}$

In the federal debate, this child protection frame was pervasive. For instance, legislators repeatedly cited statistics relating to child sexual-abuse rates and child sexual-offender recidivism rates. Not a single federal legislator provided any data regarding sex offenses againstadults. While there was some discussion of overall sexoffender recidivism rates, most legislators focused principally on the reoffense rate of child sex offenders. Representative Lofgren, the only legislator to cite particular research on rehabilitation, limited her discussion exclusively to pedophiles.Legislators could have presented data on recidivism rates of sex offenders generally; such data is available. ${ }^{274}$ Alternatively, they might have tried to link the statistics about children to overall rates of sex victimization. Instead, almost all data referred exclusively to child sex offenses.

This focus on children extended to the use of stories in the federaldebate. The laws were named after children. Again and again legislators told the story of Megan Kanka or other high-profile child victims. Yet in the course of all of this storytelling, no legislator offered a story of an adult victim. When legislators sought to prove that Megan's Law would work, they again turned to Megan's story, arguing that the bill would have saved her life. They argued that the bill might empower the community to protect other children. Legislators did not make the broader claim that the bill would protect the entire community against victimization. Surely, for example, a legislator might have offered a real, or hypothetical, story of a woman who, unbeknownst to her, was dating a rapist and who ultimately fell victim to his crime. ${ }^{275}$ Instead, legislators left stories of adult victims untold.

Even a discussion of civil rights focused entirely on children. When proponents of Megan's Law discussed the law's effects on offenders, they argued that offenders' rights should be balanced against the benefits to children. For whatever reasons, legislators chose not to frame the issue in broader terms. Certainly, they could easily have argued that victims' rights outweighed those of offenders. Repeatedly, federal legislators avoided making broad claims for Megan's Law; every argument was framed in terms of child protection.

The New York debates were little different. In their discussion of research and data, New York legislators referred exclusively to child sexual abuse. Similarly, New York legislators' storytelling focused almostentirely on children. ${ }^{276}$ Megan Kanka, Steven

273. It is, of course, possible that none of the representatives debating the laws actually knew their scope. Since the bills' sponsors participated in the debates, however, it begs credulity to suggest that nobody was aware of the unjustifiably narrow discussion frame.

274. See generally, Hanson, supra note 253.

275. Perhaps one reason why legislators eschewed real adult-victim narratives was that victims did not want their stories publicized. One New York state senator implied as much, stating that "this bill does protect as well the many women out there who maybe did not appear on the front page of a papernor would they have wanted their name or face there but, nonetheless, have been a victim of these sexual predators." N.Y. Senate, supra note 105, at 6660 (statement of Sen. Jones). This fearfor reputation, however, did not stop legislators' graphic descriptions of child rape and murder.

276. There was one exception to this focus on child-victim stories in New York. Several legislators mentioned the case of Arthur Shawcross who, on parole for killing 
Stayner, and Sherry Lindsay, ${ }^{277}$ among others, were all featured in the debate. In addition, one legislator told his own account of childhood victimization. ${ }^{278}$ Arguing for the efficacy of the bill, New York legislators also suggested that the bill might have saved children's lives, and noted that it would empower parents to better protect children. ${ }^{279}$ Several New York legislators did, however, suggest that the bill would protect not only children, but women as well. ${ }^{280}$

"Issue frames" are an essential part of political discourse. ${ }^{281}$ "Frames are more than simply positions or arguments about an issue .... [T] hey spell out the essence of the problem, suggest how it should be thought about, and may go so far as to recommend what (if anything) should be done." ${ }^{282}$ Political leaders use public venues, like legislative debates, to provide the public with these convenient shortcuts for evaluating social policy. ${ }^{283}$ Why did legislators in both jurisdictions frame Megan's Law almost exclusively in terms of child protection? Several explanations seem possible. Legislators may have been attempting to square their rhetoric with the name of the bill. If the bill was designed to protect the Megan Kankas of the world, legislators reified this narrow description of the law by ignoring all other possible beneficiaries. More likely, however, legislators selected a child-protection claim because they saw it as the most salient and convincing basis for legislative action.

Child protection has been a recurring and effective issue frame throughout the past century. ${ }^{284}$ The modern era of child protection dates to a 1962 study in the Journal of the American Medical Association entitled The Battered Child Syndrome, ${ }^{285}$ which spurred a wave of concern about physical abuse of children. ${ }^{286}$ The 1970 s featured

two children, went on to kill eighteen women. N.Y. Assembly, supra note 43, at 401 (statement of Mr. Alesi). Curiously, stories about Arthur Shawcross never involved any discussion of the victims' stories; only the story of the perpetrator. It was as if telling stories of adult female victims would somehowundermine support for Megan's Law.

277. It appears that Sherry Lindsay was a child. She was described as a daughter of a police officer, thus establishing her in her child context. N.Y. Senate, supra note 105, at 6620 (statement of Sen. Skelos). She also was described as delivering papers, which invoked images of the traditional childhood paper route. Id. Descriptions of Lindsay, however, did not reveal her age. E.g., id.; N.Y. Senate, supra note 105, at 6645 (statement of Sen. Libous). A search of the LEXIS, News Library, ALLNWS File did not reveal any additional information on this person.

278. See supra text accompanying notes 113-16.

279. See supra text accompanying notes 167-72.

280. See, e.g., N.Y. Senate, supra note 105, at 6580 (statement of Sen. DiCarlo) (stating "we've got to protect the women and children of this state"); $i d$. at 6660 (statement of Sen. Jones) (noting that bill also protects women).

281. Donald R. Kinder \& Thomas E. Nelson, Issue Frames and Group-Centrism in American Public Opinion, 58 J. POL. 1055, 1057 (1996).

282. $I d$.

283. Id. at 1057-58.

284. Several commentators have documented the centrality of child protection as an issue frame. See, e.g., BEST, supra note 58, at 3-8; JENKINS, supra note 21.

285. C. Henry Kempe et al., The Battered-Child Syndrome, 181 JAMA 17 (1962).

286. BEST, supra note 58, at 66-67. 
panic over child pornography. ${ }^{287}$ In the 1980 s, child protection advocates focused on a fear of widespread child abduction; the most memorable icon of this movement was the ubiquitous picture of a missing child on the sides of milk cartons. ${ }^{288}$ In the late 1980s, the new terror was ritual abuse, fueled by the recently discovered "recovered memory syndrome." ${ }^{289}$ Finally, by the 1990 s, child advocates perched on the issue of sexual predators. Although their claims were repeatedly refuted-child pornography was shown to be far less common than suggested, for instance, and the remarkable statistics showing mass abduction were latershown to be wildly overblown ${ }^{290}$ —child protection advocates garnered both media attention and public support. ${ }^{291}$

It is easy to see why legislators framed Megan's Law in terms of child protection. The press and the public had already shown a particular interest in the issue. More importantly, by asserting that the bill's purpose was protecting children, supporters inoculated it from attack; no sane representative would go on the record against this goal. Children are unassailable victims. Not only are they vulnerable, they are also viewed unambiguously as innocents. Unlike women, whose claims of sexual victimization have been subjected to attack, ${ }^{292}$ children are never perceived as culpable for any sexual abuse that might befall them. Legislators framed Megan's Law in terms of child protection because it provided uncomplicated, unambiguous grounds for legislative action.

287. See JENKINS, supra note 21 , at 146-54.

288. BEST, supra note 58 , at 22-24.

289. See JENKINS, supra note 21 , at 164-88.

290. Id. at 146.

291. See William S. Lofquist, Constructing "Crime”: Media Coverage of Individual and Organizational Wrongdoing, in CONSTRUCTING CRIME: PERSPECTIVE ON M AKING NEWS \& SOCIAL PROBLEMS, supra note 228, at 241, 243. One commentator has argued that media news is framed in such a way as to create a "discourse of fear." David L. Altheide, The News Media, the Problem Frame, and the Production of Fear, 38 SoC. Q. 647, 648 (1997).

292. The concept of "date rape," for example, has been repeatedly challenged on the grounds that the victims are partially culpable for their victimization. See, e.g., Twenty Questions: Camille Paglia, PlayBoy, Oct. 1991, at 132. Paglia, a bete noire of the women's movement, argues women must bear some responsibility for sexual assault:

Have twelve tequilas at a fraternity party and a guy asks you to go up to his room, and then you're surprised when he assaults you? Most women want to be seduced or lured. ... Pursuit and seduction are the essence of sexuality. It's part of the sizzle. Girls hurl themselves at guitarists, right down to the lowest bar band here. The guys are strutting. If you live in rock and roll, as I do, you see the reality of sex, of male lust and women being aroused by male lust. It attracts women. It doesn't repel them. Women have the right to freely choose and to say yes or no. Everyone should be personally responsible for what happens in life.I see the sexual impulse as egotistical and dominating, and therefore I have no problem understanding rape. Women have to understand this correctly and they'll protect themselves better.

Id. at 170; see also KATIE ROIPHE, THE MORNING AFTER: SEX, FEAR, AND FEMINISM ON CAMPUS 17-21 (1993). 


\section{Demographic Implications}

One striking difference between the debates was their differing consideration of the demographic consequences of Megan's Law. In the federal debates, little explicit discussion was dedicated to the sexual, racial, or geographic impact of the bill. While one congressman assured the House that most sexual offenders-other than the drunken stepfather-were men molesting boys,${ }^{293}$ other legislators were silent as to the likely sexual identity of sex offenders. Similarly, legislators entirely eschewed discussion of race. Perhaps most problematically, they did not discuss whether Megan's Law would have differing effects in cities versus lower-density areas. ${ }^{294}$

Legislators made demographic claims implicitly, however, through the very terms of their narratives. For instance, the great majority of child-victim stories involved white children as victims. ${ }^{295}$ Megan Kanka was a white child victimized by a white offender ${ }^{296}$ who lived in a predominately white, middle-class low-density residential community. ${ }^{297}$ Legislators neverexplicitly mentioned eitherMegan Kanka's or Jesse Timmendequas's race. Other than referring to it as Hamilton Township, nobody ever talked about Megan's neighborhood. Their failure to address these issues explicitly, however, did not make them disappear. People familiarwith the Megan Kanka saga would have seen pictures of Megan and of Timmendequas and footage of suburban Hamilton Township. ${ }^{298}$ By citing Megan Kanka, as well as Jacob Wetterling (from small-town St. Joseph, Minnesota) and Polly Klaas (from suburban Petaluma, California), ${ }^{299}$ as prototypical cases of child sexual assault, legislators implicitly suggested that Megan's Law addressed a problem of suburban (or small town) white-on-white

293. See supra text accompanying note 133.

294. See supra text accompanying note 200-01.

295. The only possible exceptions are one case involving the child of migrant workers, see supra text accompanying note 99 , and several children of unidentified race mentioned by Rep. Jackson-Lee, see, e.g., 142 CONG. REC. 10,313 (1996) (statement of Rep. Jackson-Lee) (mentioning Monique Miller); id. at 8599 (mentioning Monique Miller, Elizabeth Pena, and Jennifer Ertman). Rhetoreticians have noted that silence about race is an active, interpretable event. Crenshaw, supra note 40, at 260.

296. Interestingly, despite the fact that race was an issue in the New Jersey Supreme Court's review of Timmendequas's conviction, the court declined to state the race of either Kanka or Timmendequas. It merely noted that they "were of the same race." New Jersey v. Timmendequas, 737 A.2d 55, 79 (N.J. 1999). For whatever reasons, the LEXIS online editors were more blunt. The LEXIS syllabus of the case explicitly states that both parties were white. New Jersey v. Timmendequas, 1999 N.J. LEXIS 1007, at $* 7$ (N.J. Aug. 11, 1999).

297. Hamilton Township covers 115 square miles yet has a total population of approximately 17,000 people. Of this group, almost 13,000 residents are white and about 2360 are African-American. The overall density is approximately 147 persons per square mile. It is solidly middle class; the median family income is slightly over $\$ 44,000$ per year. County Seat of Atl. County, Statistics and Demographics of Hamilton Township, at http://www.algorithms.com/users/davies2/s tats.html (last visited Feb. 9, 2001).

298. Hamilton Township is located outside of Atlantic City, New Jersey.

299. Petaluma is located about thirty miles from San Francisco, California. 
crime. ${ }^{300}$ Senator Gramm was almost blunt, describing Ashley Estell as a resident of an "upscale suburb ... one of the finest communities in America." 301

In the New York debate, demographic issues received somewhat more consideration. One senator, forinstance, expressly asked whether Megan's Law would cover people of both sexes. ${ }^{302}$ Of course, he cautioned, it was hard to imagine a woman raping a man in the traditionalsense of rape. ${ }^{303}$ Legislators also addressed the impact of the law on cities versus lower-density areas. Critics of the bill, including legislators who ultimately voted for it, noted that it would have minimalbenefits in high-density communities and might even cause sex offenders to congregate in cities. The repeated invocation of the Megan Kanka story (as well as Assemblyman Spano's personal account) implied that the law was principally a regulation of white people. Critics' claims about the bill's impact on cities, however, contained embedded arguments about race: unlike the largely white population of New York's small towns, New York City, with its large minority population, would receive few of the benefits and suffer disproportionate costs of this new legislation. ${ }^{304}$

There were concrete reasons why legislators might have preferred Megan's Law to be viewed as regulating only whites. During the period that these laws were under consideration, commentators were drawing attention to racism within the American criminal system. ${ }^{305}$ The prosecution of O.J. Simpson spurred these feelings; one poll, taken before his acquittal, showed that eighty-seven percent of African-Americans believed Simpson was a "victim of a racist criminal justice system." ${ }^{306}$ Critics charged

300. Richard Allen Davis, who was convicted of Polly Klaas's murder, was white. Klaas Jury Hears Taped Confession, at http://www.cnn.com/US/9605/01/klaas (May 1, 1996).

301. Supra text accompanying note 104. Both Estell and the man convicted of her murder were white. Robert Riggs, DNA Tests Stir Emotions in Child Murder Case, at http://wfaa.com/wfaa/articledisplay/0,1002,11473,00.html (June 21, 2000).

302. N.Y. Senate, supra note 105, at 6605-08 (statement of Sen. Marchi).

303. Id. at 6606.

304. Although complaints about the relevance of Megan's Law to city dwellers were never couched in racial terms, one legislator commented that the legislature's failure to consider high-density areas was "a little offensive to me." N.Y. Assembly, supra note 43, at 397 (statement of Mr. Sullivan).

305. See, e.g., Cynthia Tucker, At the Fringes of Justice, A TLAnTA J.-Const., Aug. 13, 1995, at C7, LEXIS, News Library, ATLJNLFile (citing the Mumia Abu-Jamal case as reason blacks see the system as racist). Paul Butler, a law professor, made the controversial suggestion that, in order to fight racism in the criminal system, AfricanAmerican jurors should vote to acquit all black defendants in certain types of cases. PaulButler, Racially Based Jury Nullification: Black Power in the Criminal Justice System, 105 YALE L.J. 677 (1995). Because of his provocative suggestion, Butler's essay received attention in the popular media. See, e.g., Ellen Hale, Juries, SAN ANTONIO EXPRESS-NEWS, Jan. 28, 1996, at A9, 1996 WL 2818955; Frank Santiago, A Red-Hot Subject for Judges, Lawyers, DES MOINES REG., Dec. 17, 1995, at 1, 1995 WL 7224642 .

306. Richard Price, Racial Split Widens, USA TODAY, July 25, 1995, at 3 A; see also Editorial, The Fuhrman Tapes, BALT. SUN, Sept. 1, 1995, at 18A, LEXIS, News Library, BALSUN File (suggesting that the Furman tapes confirmed African-Americans' view that the criminal system was racist). 
that the Violent Crime Control and Law Enforcement Act, of which the Wetterling Act was a small part, would have a disparate impact on African-Americans. ${ }^{307}$ In this political atmosphere, it must have been a relief_and even a pleasure-to promote a bill that would not only avoid charges of racism, but might be seen as virtually inapplicable to African-Americans. Yet legislators surely knew this suggestion was false. For instance, 1995 crime statistics indicated that, as a percentage of their population, African-Americans were charged with sex crimes over twice as frequently as whites. ${ }^{308}$ Moreover, to the extent that the criminal justice system was racist, and blacks were convicted at disproportionately high rates, the law's disproportionate impact on African-Americans only increased.

The failure of federal legislators to address the question of geographical distinctions-the effects of the law on city dwellers compared to suburbanites - presumably reflected a similarpolitical expediency. By the early 1990s, a majority of American voters were suburbanites. ${ }^{309}$ A chief factor driving people to the suburbs was a search for security ${ }^{310}$ and these high-profile child murders left suburbanites highly insecure. Forlegislators fighting to secure the suburban vote, ${ }^{311}$ Megan's Laws were a welcome opportunity to address this panic. If these provisions did not have a similar beneficial effect on city voters, legislators were probably willing to seek other means to curry their support.

\section{E. Explaining Differences}

How can we explain the distinctions between the congressional and New York debates? There were three respects in which the venues differed. First, unlike the relatively private New York discussions, the federaldebates were nationally televised. Second, the New York legislature was more ideologically diverse than Congress. And third, the New York debate was structured to encourage more back and forth discussion.

One big reason why the Congressional debate featured more vivid stories and dramatic statistics, and less focus on the substantive benefits and costs of Megan's Law, may have been the presence of C-SPAN. Federal legislators know they command

307. Carl T. Rowan, Atrocious Crime Bill Must Die, CHI. Sun-TimES, July 29, 1994, at 29 (suggesting that death penalty provisions would have disparate racialimpact).

308. In 1995, for instance, $42.4 \%$ of all individuals arrested for forcible rape and $22.6 \%$ of all individuals arrested for sex charges other than forcible rape and prostitution were black. BUREAU OF JUSTICE STATISTICS, U.S. DEP'T OF JUST., SOURCEBOOK OF CRIMINAL Justice STATISTICS 1996, at 383 (Kathleen Maguire \& Ann L. Pastore, eds. 1996). African-Americans make up only thirteen percent of the nation's total population. JESSE MCKINNON \& KAREN HUMES, THE BLACK POPULATION IN THE United States 1 (U.S. Census Bureau, Current Populations Report Series P20530, 1999), available at http://www.census.gov/prod/2000pubs/p20-530.pdf.

309. William Schneider, The Suburban Century Begins: The Real Meaning of the 1992 Election, ATLANTIC, July 1992, at 33.

310. Id.

311. The 1992 election featured a fight for suburban voters. Id. Because of the larger size of their electoraldistricts, a larger portion of federal legislators probably relied on suburban votes than did their New York counterparts. 
a national audience ${ }^{312}$ and they know this audience is particularly influential. Thus, unlike New York legislators who may have perceived the debates more as an interpersonal discussion between colleagues, members of Congress seemed to play to the cameras. Vivid stories and bold statistics are more dramatic and more likely to draw in the casual channel surfer. They also make for better clips on the television news. As a result, legislators may have focused on these media friendly aspects of the debate, eschewing the dull, nuts-and-bolts issues, and avoiding complicated questions relating to the efficacy and costs of Megan's Law.

A second distinction between the two legislatures was ideological. Unlike Congress, the New York legislature included representatives on both sides of the Megan's Law issue. ${ }^{313}$ This diversity had a concrete impact on the debates as a whole. New York Megan's Law opponents achieved two different things. By challenging proponents' claims for the law, they forced these supporters to sharpen and narrow their arguments. Rather than rely on rhetorical flourish, New York supporters of the bill provided more relevant statistics while at the same time conceding the significant limitations of the law. Opponents also succeeded in expanding the scope of the debate, articulating concerns about the law that never surfaced in Congress.

A final difference between the two debates was structural. Because the New York debates each occurred on single days, centered on a single bill, supporters and opponents were able to engage in an active, focused dialogue about Megan's Law. Combined with the chambers' ideological diversity, this structure may have encouraged more wide ranging and thorough discussion of issues. In Congress, on the other hand, the Megan's Law debate took the form of speeches, rather than focused debate, allowing easy avoidance of complex issues and questions.

312. Indeed, federal legislators clearly believed they were being watched. In the course of the U.S. congressional debate overMegan's Law, legislators made several references to the viewing audience. In one case, a congressman showed a photo of Jacob Wetterling - a boy who was missing from Minnesota and after whom the first federal Megan's Law bill was named — in case any viewers might have seen him. 139 CONG. REC. 31,251 (1993) (statement of Rep. Ramstad) ("Next to me are two photographs . . of Jacob, which I hope the camera will capture . . . I hope if anyone watching recognizes Jacob they will call 1-800-843-5678.”).

On anotheroccasion, Representative Dornan implored viewers to get copies of the day's Congressional Record so they could see an article, included in the Record, entitled Pedophilia Chic. 142 CONG. REC. 17,114 (1996) (statement of Rep. Dornan). In some cases, legislators did not attempt to take advantage of the likely viewership, but acknowledged it nonetheless. See, e.g., 142 CONG. REC. 24,846 (1996) (statement of Rep. Watt) (noting that his comments would engender many phone calls).

313. The New York State Assembly, controlled by Democrats, was typically seen as liberalwhile the state's senate was viewed as conservative. Symposium, supra note 20, at 39 (comments of Robert T. Farley). 


\section{A SSESSING THE RHETORIC OF MEGAN'S LAW}

The federal and New York Megan's Law debates offered strong claims for new regulations on child sex offenders. They contained partisan language, as well as various rhetorical tropes-like the extensive u se of storytelling-designed to establish the incontrovertible need for Megan's Law. Yet for all their power, it remains unclear whether they met the three purposes legislative debate typically seems to serve: influencing voting decision, educating the media and the public, and establishing a historical record for the purpose of judicial interpretation. ${ }^{314}$

It is very difficult to assess whether the rhetoric of the Megan's Law debates resulted in vote shifting. Two things are known. First, three opponents of the 1996 Megan's Law changed their votes after the initial ballot, causing the bill to be approved unanimously. ${ }^{315}$ Second, several New York legislators who expressed reservations about Megan's Law ultimately voted for the bill. Legislators no doubt felt much public pressure to support the legislation; whether or not rhetoric played a part in legislators' decisions to follow the popular will is hard to gauge.

Clearly, Megan's Law supporters used rhetoric designed to make opposition to the law politically impossible. They employed a three-part rhetorical strategy that advocates have used previously to push public support for other child protection legislation:typification, statistical manipulation, and melodrama. During the late 1980s, forinstance, advocates argued fornew strangerchild-abduction laws by making these same three claims.First, citing particularly horrible, well-publicized abductions-cases like the Jacob Wetterling incident-they argued that these incidents were typical of the broader abduction problem. ${ }^{316}$ Second, they grossly exaggerated the extent of the crisis, pointing to the high rate of total child abductions (a number which consisted largely of parental kidnappings) as evidence of a massive stranger abduction crisis. ${ }^{317}$ Finally, they described their political struggle as a melodrama: a battle of good (child protectors) versus evil (child abusers). ${ }^{318}$ As a result of this effective rhetoric, activists successfully convinced the public that stranger child abduction was a scourge sweeping the nation. ${ }^{319}$

Legislative advocates for Megan's Law used these same techniques. They typified child sexabuse by reference to particularly horrific rape and murdercases; they framed the problem by reference to irrelevant or deceptive statistics; and, by using dehumanizing language, they turned the fight against child sex abuseinto melodrama. The se claims were designed to capture public attention, and short-circuit any reasoned debate about the proposed law. Given the effectiveness of these techniques in prior public-policy campaigns, opponents of Megan's Law could reasonably have concluded that the public would view their opposition to Megan's Law as not only irresponsible, but active promotion of the force of evil.

314. See supra Part I.A.

315. See supra note 13 and accompanying text.

316. BEST, supra note 58, at 71.

317. Id. at 46-50, 59.

318. See Joel Best, Random Violence: How We TAlK A bout NeW CRIMES AND

NEW VICTIMS 89-90 (1999); BEST, supra note 58, at 5-6.

319. BEST, supra note 58, at 151-75. 
The Megan's Law debates offered some educational benefits to the public. Because congressional debate was available via C-SPAN, it is likely that media and political elites, as well as the public, were privy to the legislative dialogue. What sorts of education did these debates confer, however? For those citizens who had not heard of these high-profile cases previously, the debate served as notice that parents must consciously protect their children. It is less clear, however, whether the federaldebate provided listeners a fair understanding of the scope or nature of the nation's child sexual abuse problem. Through the various rhetoric techniques discussed above, legislators inaccurately characterized child sex abuse as manifesting itself principally in the form of abduction followed by rape (and sometimes murder) ${ }^{320}$ In fact, the vast majority of child sex abuse occurs at the hands of relatives or acquaintances; almost fifty percent of all offenders are parents or parental figures. ${ }^{321}$ Legislators also failed to link the proposed law to the abuse problems they identified; they never explained whether Megan's Law would do anything to protect the large numbers of children "abused and neglected," "abducted," or "victimized."

Megan's Law supporters in Congress also did little to educate the public about the policy concerns surrounding Megan's Law. They failed to tell the public that the bill, although cast as a regulation of offenders who sexually molest children, was really a regulation of a wide array of sexual offenders as well as certain offenders who had never engaged in any sexual misconduct. They did not address the potentially significant economic costs of the bill. ${ }^{322}$ They failed to explore, and even misrepresented, the demographic impact of the legislation. Finally, they never discussed the forces that might have contributed to sexualabuse and spent little time confronting the social costs of the bill.

Although fewer people heard the New York debate, it provided a substantively better education to those listeners. Legislators did frame the child sexual abuse problem in somewhat misleading ways, of course, and they also incorrectly implied that the bill was limited to child sexoffenders. But because of active opposition to the provision, supporters conceded that the law would not significantly reduce the child sexual abuse problem. Opponents also alerted listeners to the bill's social costs and disparate demographic impact. Moreover, legislators spent some time discussing the bill's practical details. A person listening to the debate would have learned, for instance, that the bill created a 900 phone number for concerned neighbors $;{ }^{323}$ that the public would have to go to the police station to view offenders' pictures; $;{ }^{324}$ and that offenders would be entitled to counsel at the time of their risk assessment hearing. ${ }^{325}$

Finally, the Megan's Law debates provided potentially valuable material for the purpose of judicial interpretation. While members of Congress made almost no effort to flesh out the details of the bill, New York legislators did explain how certain portions of Megan's Law were to be applied. More importantly, legislators in both venues offered suggestions about the purpose of the bill. Many were explicit that the bill was

320. See supra text accompanying notes 258-63.

321. Roxanne Lieb et al., Sexual Predators and Social Policy, 23 CRIME \& JUST. 43, 50 (1998).

322. Koenig, supra note 187 , at 763.

323. N.Y. Assembly, supra note 43, at 331-37 (back-and-forth discussion).

324. Id. at 327-29 (back-and-forth discussion).

325. N.Y. Senate, supra note 105, at 6632-33 (back-and-forth discussion). 
designed to protect the community. Yet beyond these comments, reviewing courts could find other material that would aid their interpretation of the laws. Imbedded in the various speeches were expressions of anger against offenders. These comments led one court to conclude that the true intent of the New York Megan's Law was not public safety, but rather punishment and retribution. ${ }^{326}$ This example suggests that, whether or not legislators intend to shape judicial interpretation of a bill, their comments may prove valuable to a reviewing court.

What then can we conclude about the rhetoric of this one-sided debate? What differences surface when comparing Congress's entirely one-sided discussion with New York's slightly more adversarial model? First, it appears that even one-sided debate can produce passionate and substantive discussion of new law. Legislators in both venues spoke out forcefully for Megan's Law; federal legislators did not offer a weaker appeal simply because they faced no challenge. Second, it is clear that Congress's nonadversarial debate was driven less by a need for a comprehensive discussion and explication of the law, and more by theater. When legislators felt unchallenged in debate, they were free to argue in vivid and dramatic, if at times misleading, terms. In New York, on the other hand, even a small number of opponents were able to significantly broaden debate, and force proponents to admit some of the bill's weaknesses. Third, it seems that even in a one-sided debate, the public will receive some information about new legislation. The information will not necessarily be tempered by honest discussion of the bill's limitations, however. Finally, it is evident that even nonadversarial debate can provide valuable rhetorical material that courts can use to interpret the law.

It is difficult to know whether legislatures can improve the quality of debate about bills, like Megan's Law, that enjoy widespread legislative and popular support. Any effort to eliminate particular rhetorical tropes would be not only practically impossible, but ill-advised. Barring the use of stories would not improve lawmaking because vivid storytelling can promote both good and bad social policy. Similarly, it would be foolish to eliminate the use of statistics in legislative debate simply because they are subject to manipulation. Legislatures should attempt to identify the nature and extent of a problem before they act and statistics can be a valuable tool in this analysis. Nonetheless, legislatures ought to consider at least two possible approaches to improving and enriching the rhetoric of debate.

One direction forimprovement might be creation of a "public advocate," a legislative equivalent to the judiciary's public defender. This person would be empowered to participate in legislative debate when a bill has little or no opposition. This public advocate might be allowed to participate upon the (possibly anonymous) request of only one legislator. She might argue reasons to oppose a law, challenge claims made by a provision's supporters, or suggest better alternatives to the bill. She could introduce counternarratives that might challenge assumptions of the majority. Her sole job would be to insure that no law was adopted without the valuable benefits conferred by a full, honest, and comprehensive debate.

As a second approach to improving legislative debate, legislatures might consider creating their own "code of debate." These aspirational rules would be designed to

326. Doe v. Pataki, 940 F. Supp. 603, 605, 621-22 (S.D.N.Y. 1996), aff'd in part and rev'd in part, 120 F.3d 1263 (2d Cir. 1997). 
encourage legislators to offer honest claims and address the full panoply of policy concerns. For instance, legislators might be bound to tell stories ethically. One commentator has suggested, for instance, that fair storytelling requires storytellers to "1) rely upon a broad factual basis; 2) demonstrate clear regard for interpersonal complexities; 3 ) emphasize the psychological apparatus and intentional states of mind of the participants; and 4) acknowledge the narrator's bias." ${ }^{327}$ Legislators might also be asked to explain the precise nature of their statistical claims and provide citations to applicable studies. A bill's supporters might be bound to discuss various shortcomings of the bill and explain why it is nonetheless a sound policy choice.

Neither of these proposals is by any means a panacea. Nonetheless, they suggest that improving legislative debate is not impossible. At minimum, legislators should begin to examine their own rhetoric, as well as the reasons they engage in debate, to assure that they, and their legislative institutions, are doing their best to make the process fair, honest, and productive.

\section{CONCLUSION}

The study of legislative rhetoric, even the one-sided Megan's Law debate, has unearthed interesting, and telling, material. This Article establishes not only that such rhetoric is consequential, but that there is a need for other scholars to begin to take legislative rhetoric seriously. Legislators, courts, and the public at large will all benefit from future research in this area. Rhetoric is a potent tool, all the more so when employed in the public legislative chamber. In the end, legislatures, and individual legislators, must take responsibility for using this rhetoric in positive ways, and scholars can work to assist elected officials in this important quest.

327. Troutt, supra note 37 , at 96. 